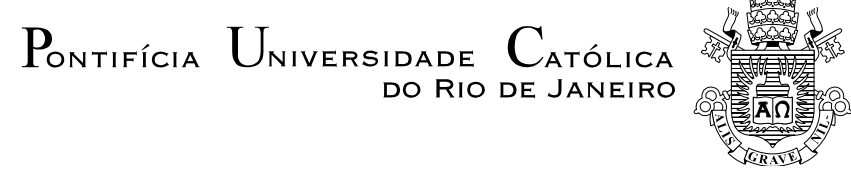

Claudia Macedo

Evasão estudantil nos cursos de matemática, química e física da Universidade Federal Fluminense: Uma silenciosa problemática

Dissertação de Mestrado

Dissertação apresentada ao Programa de Pósgraduação em Serviço Social da PUC-Rio como requisito parcial para obtenção do título de Mestre em Serviço Social.

Orientador: Profa. Andréia Clapp Salvador 


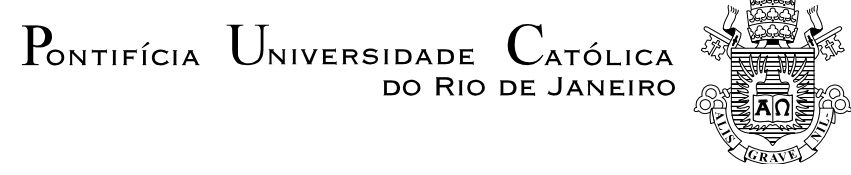

Claudia Macedo

\section{Evasão estudantil nos cursos de matemática, química e física da Universidade Federal Fluminense: Uma silenciosa problemática}

Dissertação apresentada como requisito parcial para obtenção do grau de Mestre pelo Programa de PósGraduação em Serviço Social do Departamento de Serviço Social do Centro de Ciências Sociais da PUC-Rio. Aprovada pela Comissão Examinadora abaixo assinada.

Profa. Andréia Clapp Salvador

Orientador

Departamento de Serviço Social - PUC-Rio

Profa. Ilda Lopes Rodrigues da Silva Departamento de Serviço Social - PUC-Rio

Profa. Nadia Filomena Ribeiro da Silva

UFF

Profa. Mônica Herz

Vice-Decana de Pós-Graduação do Centro de Ciências Sociais - PUCC-Rio

Rio de Janeiro, 02 de julho de 2012 
Todos os direitos reservados. É proibida a reprodução total ou parcial do trabalho sem autorização da universidade, da autora e da orientadora.

\section{Claudia Macedo}

Graduou-se em Serviço Social pela Faculdade de Serviço Social do Rio de Janeiro em 1981. Especializou-se em Docência Superior e Terapia de Família pela Universidade Cândido Mendes em 2008. Trabalha como Assistente Social e Coordenadora de Apoio Social na Universidade Federal Fluminense. Áreas de interesse: Assistência Estudantil no Ensino Superior.

Ficha Catalográfica

Macedo, Claudia

Evasão estudantil nos cursos de matemática, química e física da Universidade Federal Fluminense: uma silenciosa problemática / Claudia Macedo ; orientadora: Andréia Clapp Salvador. - 2012.

106 f. : il. color. ; $30 \mathrm{~cm}$.

Dissertação (mestrado)-Pontifícia Universidade Católica do Rio de Janeiro, Departamento de Serviço Social, 2012.

Inclui bibliografia.

1. Serviço social - Teses. 2. Ensino superior. 3. Evasão estudantil. 4. Assistência estudantil. I. Salvador, Andréia Clapp. II. Pontifícia Universidade Católica do Rio de Janeiro. Departamento de Serviço Social. III. Título. 
Dedico este trabalho Aos meus filhos Pamella e João Gabriel Ao meu companheiro João Neto pelo apoio incondicional. 


\section{Agradecimentos}

Meus agradecimentos as pessoas que fizeram parte dessa história.

Ao Nosso Senhor e ao Espírito Santo que iluminou cada momento na construção deste trabalho.

A professora Andréia Clapp minha orientadora, pessoa fundamental para a elaboração deste trabalho.

A minha amiga Cristiane pelo apoio e atenção durante este período de trabalho.

As minhas amigas da Célula da Igreja Betaninha, que através das orações me deu força e sustento.

Aos meus pais que compreenderam e respeitaram meu período de reclusão durante a elaboração deste trabalho

À PUC-Rio, pelos auxílios concedidos, sem os quais este trabalho não poderia ter sido realizado.

Aos meus entrevistados que confiaram e respeitaram o meu trabalho. 


\section{Resumo}

Macedo, Claudia; Salvador, Andréia Clapp. Evasão estudantil nos cursos de matemática, química e física da Universidade Federal Fluminense: Uma silenciosa problemática. Rio de Janeiro, 2012. 106p. Dissertação de Mestrado - Departamento de Serviço Social, Pontifícia Universidade Católica do Rio de Janeiro.

A presente dissertação tem como objetivo conhecer os fatores que ocasionam a evasão escolar no ensino superior, com enfoque específico sobre os Cursos de Licenciaturas em Matemática, Química e Física da Universidade Federal Fluminense no ano de 2009. A UFF caracteriza evasão estudantil em 09(nove) categorias. Este estudo propõe pesquisar a categoria evasão por abandono de curso. Para contextualizar a pesquisa foi realizado um resgate da história do Ensino Superior no Brasil e da Assistência Estudantil no Ensino Superior, foram realizadas ainda algumas reflexões a respeito do papel social da universidade e sobre as questões que permeiam o problema da evasão escolar no ensino superior. No desenvolvimento do trabalho utilizaram-se dados quantitativos e qualitativos. A coleta de dados foi realizada através de entrevistas semi-estruturadas baseada em um roteiro previamente definido com 12 (doze) exestudantes, distribuídos do seguinte modo: 06 (seis) Matemática, 03 (três) Química e 03 (três) Física. Nas últimas décadas houve um aumento significativo de vagas para o ensino superior o que possibilitou maior acesso aos estudantes às universidades públicas e privadas, no entanto, houve também um aumento do número de estudantes que não conseguiu por diversos motivos concluir os seus cursos. Com base nesta situação, esta pesquisa buscou identificar quais os fatores determinantes que levaram os estudantes entrevistados a abandonarem os seus cursos. Em nosso trabalho também foi elaborado o perfil do estudante evadido considerando suas características socioeconômicas e educacionais atuais. Ainda neste trabalho foi identificado o grau de participação dos estudantes evadidos nos programas de bolsas acadêmicas ou da assistência estudantil visando à permanência dos mesmos na universidade. 


\section{Palavras-chave}

Ensino Superior; Evasão Estudantil; Assistência Estudantil. 


\section{Abstract}

Macedo, Claudia; Salvador, Andréia Clapp. (Advisor). Student evasion in Mathematics, Chemistry and Physics courses at the Federal University Fluminense: a silent problem. Rio de Janeiro, 2012. 106p. MSc. Dissertation - Departamento de Serviço Social, Pontifícia Universidade Católica do Rio de Janeiro.

This thesis aims to identify the factors that cause school evasion in higher education, focused specifically on Mathematics, Physics and Chemistry undergraduate courses of the Universidade Federal Fluminense in 2009. The university characterises student evasion in 09 (nine) categories. This study proposes to investigate the school evasion by courses abandonment. To contextualize this research was recovered the understanding about the history of higher education in Brazil and Student Assistance in Higher Education, furthermore some reflections were done about the social role of the university and the issues that cross the school evasion problems in higher education. To develop this work were used quantitative and qualitative data. The data capture was performed through semi-structured interviews based on a predetermined route with 12(twelve) ex-students, distributed as follows: 06 (six) Mathematics, 03 (three) and Chemistry 03 (three) physics. In the last recent decades there has been a significant increase of vacancies for higher education which allowed more access to students at public and private universities, however, there was also an increase of students who for various reasons, could not complete their courses. Based on this situation, this study sought to identify the factors that stimulated the students interviewed to leave their courses and was designed this student profile considering its current socioeconomic and educational situation. Also, this work identified the participation degree of the students that left their courses in programs of scholarships or student assistance in order to promote their permanency in the university. 


\section{Keywords}

Higher Education; Student Evasion; Student Assistance. 


\section{Sumário}

Introdução

1. O Ensino Superior no Brasil, a Evasão Universitária

20

e a Política de Assistência Estudantil no Ensino

Superior - Algumas Considerações

1.1. A Trajetória do Ensino Superior no Brasil

1.2. O Papel Social da Universidade

1.3. A Evasão no Ensino Superior 39

1.4. A Assistência Estudantil no Ensino Superior 44

1.5. A Assistência ao Estudante da UFF: Programas 51 de Bolsas da Assistência Estudantil

2. Analisando Trajetórias e Percepções 55

2.1. Procedimentos Metodológicos da Pesquisa 55

2.2. O Perfil dos Estudantes Entrevistados 60

2.3. Análise dos Dados: As Narrativas dos Estudantes 65 Evadidos

2.3.1. A Trajetória do Estudante Evadido 66

2.3.2. Os Motivos da Evasão nos Cursos das 73

Licenciaturas: Matemática, Química e Física

2.3.3. Propostas dos Estudantes para Evitar a 78

Evasão Universitária

3. Considerações Finais

81

4. Referências Bibliográficas $\quad 84$

5. Apêndices 92

$\begin{array}{ll}\text { 6. Anexos } & 97\end{array}$ 


\section{Lista de Quadros}

Quadro 1- Entrevistados - Por curso de graduação pesquisado

Quadro 2- Entrevistados - Por local de origem/moradia

Quadro 3- Entrevistados - Por curso e atividade profissional

Quadro 4- Entrevistados - Por período em que desvinculou 68 do curso

Quadro 5- Entrevistados - Por situação acadêmica atual

69 (2012) 


\section{Lista de Gráficos}

Gráfico 1- Entrevistados - Por faixa etária 60

Gráfico 2- Entrevistados - Por sexo 61

Gráfico 3- Entrevistados - Por estado civil 61

Gráfico 4- Entrevistados - Por escolaridade dos pais 62

Gráfico 5- Entrevistados - Por renda média familiar (Em 63 salários mínimos)

Gráfico 6- Entrevistados - Por tipo de escola no ensino 64 médio

Gráfico 7- Numero de vestibulares prestados - Por curso 64 de graduação pesquisado

Gráfico 8- Exercício de atividade remunerada durante a 66 trajetória escolar

Gráfico 9- Participação em Programas de Bolsas da Assistência Estudantil e Acadêmica 


\section{Lista de Siglas}

ANDIFES- Associação dos Dirigentes das instituições Federais de Ensino Superior.

ABEP- Associação Brasileira de Estudos Populacionais

CNPq - Conselho Nacional de Desenvolvimento Científico e Tecnológico

CF- Constituição Federal

CR- Coeficiente de Rendimento

DAC - Departamento Assuntos Comunitários

DAE- Departamento Assistência Estudantis

DAS - Departamento Assistência social

FONAPRACE - Fórum Nacional de Pró-Reitores de Assuntos

Comunitários e Estudantis

GT - Grupo de Trabalho

HUAP - Hospital Universitário Antonio Pedro

IBGE- Instituto Brasileiro de Geografia e Estatística

INEP- Instituto Nacional de Ensino e Pesquisa

IFES - Instituição Federal de Ensino Superior

ID- Identificação

IES- Instituição de Ensino Superior

LDB- Lei de Diretrizes e Bases da Educação

LOAS- Lei Orgânica da Assistência

MEC- Ministério da Educação e Cultura

PNAES- Programa Nacional de Assistência Estudantil

PROUNI- Programa Universidade para Todos

PNE- Plano Nacional de Educação 
PROAES- Pró-Reitoria de Assuntos Estudantis

REUNI- Reestruturação e Expansão das Universidades Federais

SESU- Secretaria de Ensino Superior

SUAS- Sistema Único de Assistência Social

UFG- Universidade Federal de Goiás

UFF- Universidade Federal Fluminense

UFRJ- Universidade Federal do Rio de Janeiro

UFERJ- Universidade Federal do estado do Rio de janeiro

UFPE- Universidade Federal de Pernambuco

UNESCO- Organização das Nações Unidas para a educação, a ciência e a cultura

UNB- Universidade de Brasília

UNIMONTES- Universidade Estadual de Montes Claros 
Desejar não basta; para tornar o desejo realmente desejável e assim extrair prazer do desejo, deve-se ter esperança racional de chegar mais perto do objeto desejado. 


\section{Introdução}

A presente dissertação de mestrado emergiu a partir das vivências profissionais $^{1}$ no âmbito da educação superior pública, em especial na PróReitoria de Assuntos Estudantis (PROAES) da Universidade Federal Fluminense $(U F F)^{2}$. Pretende-se, com este trabalho, estabelecer reflexões sobre a política de educação superior, com ênfase na questão da evasão estudantil. Analisar e compreender o fenômeno da evasão na universidade constitui, em nosso entendimento, uma necessidade urgente.

A temática evasão no ensino superior tem permeado frequentemente os debates relacionados à permanência dos estudantes nas universidades públicas. No Brasil, a questão se apresenta com força a partir do ano de 1995, por meio da Comissão Especial de Estudos sobre Evasão nas Universidades Públicas Brasileiras, instituída pelo MEC. Para a Comissão, a evasão consiste na saída definitiva do estudante de seu curso de graduação, sem antes concluí-lo.

Estudos apontam (Theóphilo, 2005; Silva Filho (2005); Polydoro, 1995; Ribeiro, 2005) que questões como mudança de curso e a decepção diante das expectativas criadas diante da universidade são alguns dos fatores que levam à evasão. As transformações expressivas trazidas pela universidade à vida do estudante como, por exemplo, a didática utilizada nas aulas e o relacionamento com colegas de classe que possuem um capital diferenciado, também contribuem para a evasão no ensino superior.

Um aspecto a ser considerado quando se investiga a causa da evasão nas universidades, sejam públicas ou privadas, diz respeito às estratégias de mobilidade social traçada pelos estudantes. Em consequência de suas condições socioeconômicas, alguns desistem de buscar as carreiras mais concorridas e/ou de sua preferência e "optam" por cursos menos procurados, mesmo tendo pouco interesse em ingressar, de fato, na profissão "escolhida".

\footnotetext{
1 Atualmente exerço minhas atividades profissionais na PROAES/UFF onde atuo como Coordenadora de Apoio Social.

${ }^{2}$ A Universidade Federal Fluminense foi criada pela Lei oㅡ 3.848, de 18 de dezembro de 1960, com o nome de Universidade Federal do Estado do Rio de janeiro - UFERJ. Hoje, a universidade conta com 32.753 estudantes matriculados, 2.941 professores efetivos e 4.705 servidores técnicoadministrativos. São 86 cursos de graduação, 98 cursos de pós-graduação stricto sensu e 141 cursos de pós-graduação lato sensu. A UFF está presente em Niterói e em outros nove municípios do Estado do Rio de Janeiro. Também possui 01 campus avançado em Belém do Pará.
} 
Para estes estudantes, o que interessa no momento é ingressar em um nível educacional diferenciado, cujo título poderá contribuir para sua mobilidade social. A escolha em questão vai sendo moldada a partir de um conhecimento prático - não necessariamente consciente - daquilo que está ou não ao seu alcance. Apreendido por Bourdieu (1998) como causalidade do provável, tais estudantes internalizam suas possibilidades objetivas de acesso a bens materiais e/ou simbólicos e exteriorizam subjetivamente, adequando suas possibilidades de êxito de acordo com o lugar que ocupam no espaço social. Este fato se dá através das experiências de sucesso e insucesso acumuladas historicamente que influenciam nas escolhas dentro da realidade social em que estão inseridos.

Esta pesquisa tem como objetivo identificar as causas da evasão nos cursos de graduação da UFF. Os cursos escolhidos foram Licenciatura em Matemática, Química e Física, tomando como ano base 2009. Tal escolha se justifica uma vez que os dados ${ }^{3}$ apontam que entre os cinco primeiros cursos que apresentaram o maior número de evasão na UFF no período de 1/2000 e 1/2005, três são essas licenciaturas ${ }^{4}$.

Para a realização desta pesquisa foi utilizado o método qualitativo, que se caracteriza como um "método que trabalha com os valores, crenças, atitudes e opiniões" (Minayo, 2008, p.247.) Desta forma, valoriza-se o olhar sobre a realidade de cada estudante evadido, sua trajetória durante o curso e sua perspectiva após sua saída da universidade.

Utilizou-se como base para a produção dos dados, um roteiro para as entrevistas semi-estruturado, que "combina perguntas fechadas e abertas, em que o entrevistado tem possibilidade de discorrer sobre o tema em questão sem se prender à indagação formulada" (Minayo, 2008, p.64). A partir do levantamento dos dados, foi possível compor o perfil dos estudantes evadidos no ano de 2009, destacando-se elementos como sexo, estado civil e escolaridade dos pais. Deve-se destacar que o ano de 2009 foi selecionado para o nosso estudo devido ser o primeiro ano após a implantação do Programa Nacional da Assistência Estudantil - PNAES.

Durante a realização das entrevistas, busquei conhecer as relações objetivas e subjetivas nas quais o entrevistado estava inserido e as suas

\footnotetext{
${ }^{3}$ Dados disponibilizados pela Superintendência da Tecnologia da Informação STI da Universidade Federal Fluminense.

${ }^{4}$ As questões referentes ao resultado da pesquisa serão aprofundadas no Capítulo II deste estudo.
} 
percepções quanto à evasão estudantil, bem como, procurou-se levantar as propostas de programas de permanência sugeridas pelos estudantes evadidos.

No total foram entrevistados 12 (doze) ex-estudantes, utilizando um roteiro previamente definido (anexo 01).

Os estudantes evadidos foram escolhidos aleatoriamente, subdivididos de acordo com o percentual estimado para amostra de $10 \%$ do quantitativo total entre os cursos examinados, ou seja: Matemática - seis estudantes; Química três estudantes; Física - três estudantes entrevistados. A UFF categoriza evasão da seguinte maneira: cancelamento por solicitação oficial; cancelamento da matrícula pelo vestibulando; cancelamento por desistência de mudança de curso; cancelamento por insuficiência de aproveitamento; cancelamento por abandono; cancelamento por casos especiais; cancelamento por liminar cassada; cancelamento por motivo de falecimento e transferência para outra Instituição de Ensino Superior. Esta pesquisa investigará a categoria cancelamento por abandono por considerar que esta categoria acorda melhor com o sentido de evasão.

Neste sentido, entende-se que a entrevista é uma conversa, um diálogo, em que o roteiro, ainda que previamente elaborado, é flexível. Sobre a interação entrevistado-entrevistador, Velho (1989) versa que:

\begin{abstract}
Lido com indivíduos que narram suas experiências, contam suas histórias de vida para um pesquisador próximo, às vezes conhecido. As preocupações, os temas cruciais são, em geral, comuns a entrevistado e entrevistador. A conversa não é sobre crenças e costumes exóticos à socialização do pesquisador. Pelo contrário, boa parte dela faz referência a experiências históricas, no sentido mais amplo, e cotidiano também do meu mundo, e as minhas aflições e perplexidades. Eu, o pesquisador, ao realizar entrevistas e recolher histórias de vida, está aumentando diretamente o meu conhecimento sobre a minha sociedade e o meio social em que estou mais diretamente inserido, ou seja, claramente envolvido em um processo de autoconhecimento. (Velho, 1989,p.17)
\end{abstract}

Conhecer a trajetória dos estudantes evadidos, as condições de permanência desses dentro do espaço da universidade, fazem com que "o registro e a sistematização e análise das falas dos entrevistados, assuma um foco central, pois na análise o propósito é ir além do descrito, fazendo uma decomposição dos dados e buscando as relações entre as partes que foram decompostas e, por ultimo, na interpretação (grifo da autora) - que pode ser feita após a análise ou após a descrição - buscam-se o sentidos das falas e das ações para se chegar a uma compreensão ou explicação que vão além do descrito e analisado". (Minayo, 2008, p.80). 
Neste contexto, o estudo sobre evasão no ensino superior, torna-se fundamental, como também, realizar uma avaliação sobre as políticas de permanência implantadas nas Universidades, desta forma analisar se estas estão atingindo os seus propósitos e objetivos de combater e/ou minimizar os efeitos da evasão universitária. Para tal precisamos entender melhor este fenômeno que atinge o ensino superior público.

A seguir apresento a estrutura do trabalho: No capítulo I pretende-se abordar a trajetória do ensino superior no Brasil, o papel social da Universidade e a questão da evasão escolar no Ensino Superior. Para isto realizei um levantamento histórico da Assistência Estudantil no Ensino Superior, da Assistência Estudantil na UFF e também os Programas de Bolsas da Assistência Estudantil.

No Capítulo II analiso as entrevistas realizadas com os estudantes evadidos, as percepções dos entrevistados quanto os motivos que levaram a abandonar o curso, as estratégias de permanência, isto é, se participou de algum programa de bolsas/auxílios da assistência estudantil ou de programas acadêmicos; sua trajetória de vida após deixar a universidade e as sugestões de programas e ou ações apontadas pelos entrevistados a fim de evitar a evasão universitária e proporcionar uma vida universitária na sua plenitude.

O trabalho encerra-se com reflexões sobre esta realidade, buscando contribuir para a construção de políticas públicas e sociais, bem como promover o debate sobre a questão da evasão no ensino universitário. 


\section{O Ensino Superior no Brasil, a Evasão Universitária e a Assistência Estudantil no Ensino Superior - Algumas Considerações}

Neste capítulo serão abordados alguns aspectos sobre a trajetória da política educacional no Brasil, onde será feita uma breve retrospectiva histórica acerca das políticas criadas para a educação, em especial para a educação superior.

Refletir sobre o papel social da universidade e sobre as ações voltadas para a democratização do acesso e a busca por maior qualidade na permanência dos estudantes nas universidades públicas, são temas relevantes na discussão a respeito do ensino superior no Brasil.

Para finalizar este capítulo, serão examinadas questões referentes à evasão universitária e as políticas voltadas para a assistência ao estudante.

\section{1.}

\section{A Trajetória do Ensino Superior no Brasil}

O ensino superior no Brasil é marcado por seu caráter elitista. Em seu primeiro momento (1808), as primeiras faculdades brasileiras tinham por objetivo atender à demanda da Corte Portuguesa, recém-instalada no Rio de Janeiro. Seu público era basicamente composto pelos filhos da elite brasileira, grandes comerciantes, filhos de nobres que, antes eram enviados às universidades européias (França e Portugal) para prosseguirem suas carreiras escolares. (Buarque, 1994).

Buarque (1994) versa que a criação das primeiras faculdades brasileiras, voltadas principalmente para a formação tecnológica (Engenharia de Minas, Medicina e Direito) consistia em formar profissionais que iriam mais tarde ocupar cargos na burocracia estatal. Com isto, as universidades foram criadas de forma 
diferentes das demais universidades dos países latinos de colonização espanhola.

Diferentemente dos demais países latino-americanos de colonização espanhola, o Brasil não teve universidades renascentistas criadas nos primeiros séculos de colonização. A universidade brasileira foi concebida segundo os modelos dos países desenvolvidos, comprometidos com a eficiência de cada faculdade independente. (Buarque,1994, p.103).

Essa diferença apontada por Buarque marca a história da universidade brasileira, que teve sua constituição voltada para a profissionalização, em especial para as atividades relacionadas ao ensino e a admissão dos estudantes nas faculdades.

\footnotetext{
O nosso ensino superior é profissionalizante desde a chegada da família real ao Brasil, em 1808. A universidade brasileira ao ser criada em 1920, se limitou praticamente ao desenvolvimento das atividades de ensino. Cada faculdade possuía um ou mais cursos que the conferiam a identidade e, através de vestibular específico, selecionava os candidatos às vagas que oferecia. (1994.p.103)
}

No entanto, as formas de admissão ao ensino superior variaram através do tempo, mas manteve uma característica específica, a seletividade rigorosa. Esta forma de seletividade acabava por elitizar ainda mais o espaço universitário, tornando-a assim um espaço de excelência.

Tal fato nos permite dimensionar esta rigorosa seleção que exclui os segmentos mais vulneráveis economicamente da sociedade brasileira, pois são aqueles que não tiveram a oportunidade de frequentar as melhores escolas, permitindo assim maior acesso aos filhos "bem nascidos".

Daí, podemos perceber qual é o papel do ensino superior na constituição da nação brasileira, caracterizada desde o seu nascimento pelo seu caráter excludente, como afirma Anísio Teixeira (1976 p.94 e 95) "a educação é distribuída e determinada pelas condições sociais e culturais de uma sociedade". Isto significa dizer que, naquele período, a universidade se apresentava tão excludente quanto na atualidade.

A afirmação de Anibal Ponce vem corroborar com Anisio Teixeira quando afirma que: 
O sistema educacional constituiu-se a partir do momento em que a sociedade se estruturou em classes sociais antagônicas. Os interesses e as necessidades da classe social dominante passaram a delimitar o campo da Educação na medida em que passou a servir para a dominação social de poucos sobre muitos, a necessidade de se construir um aparato de dominação ideológica e intelectual, encontrou na escola e no sistema educacional o ponto de apoio (Ponce, 1982, p. 21-23).

A partir do exposto acima, pode-se entender que a raiz histórica da desigualdade educacional está atrelada à desigualdade social, reforçando a idéia da fragmentação do sistema educacional por distribuição de classes. Em nosso entendimento, isto significa que historicamente a universidade mostra-se meritocrática e elitista, sendo utilizada como instrumento de dominação.

O nascimento do ensino superior brasileiro também é marcado ainda pela precariedade e o improviso. Através do decreto $\mathrm{n}^{0} 14.343$ de 07 de setembro de 1920 foi instituída a Universidade do Rio de Janeiro, depois denominada Universidade do Brasil. Este decreto determinou que fossem reunidas como universidade, a escola Politécnica do Rio de Janeiro, a Faculdade de Medicina do Rio de Janeiro e a Faculdade de Direito do Rio de Janeiro. Esta universidade foi fechada após cumprir o objetivo de sua criação que era outorgar ao Rei da Bélgica, Alberto I, o título de Doctor honoris causa. Somente a partir de 1934, foi criada realmente uma "universidade brasileira", a Universidade de São Paulo. (Fávero, 1980)

Durante a vigência da Republica Populista, em 1931, foi instituído o Estatuto das Universidades Brasileiras ${ }^{5}$ através do Decreto ํㅜ 19.851, de 11 de abril de 1931. Nesta época estava à frente do Ministério da Educação e Saúde Pública, o professor Francisco Campos um dos mais influentes intelectuais do Estado Novo. Apesar da existência de um Estatuto, a organização da universidade continuava precária, pois este

Admitia a existência de estabelecimentos isolados como uma concessão à realidade onde estes constituíam a imensa maioria. A faculdade (de medicina, de direito, de engenharia, etc.) era a célula do ensino superior. As universidades eram compostas por faculdades que mantinham a autonomia jurídica. (Cunha, 1982, p.15)

Quando se pensava em organização do ensino superior no período populista, este era basicamente formado por escolas isoladas, havia ali mais

\footnotetext{
${ }^{5}$ Ver Decreto 19.851, de 11 de abril de 1931: Estatuto das Universidades Brasileiras. In FÁVERO, Maria de Lourdes de A. Universidade e poder: análise crítica e fundamentos históricos: 1930-1945. Rio de Janeiro, Achiamé, 1980
} 
estudantes que nas universidades propriamente ditas. As universidades brasileiras, naquele período eram nada mais que uma junção de faculdades independentes (Cunha, 1982).

Deve-se salientar que as universidades constituem-se na indissociabilidade das atividades de ensino, pesquisa e extensão e são instituições pluridisciplinares de formação de profissionais de nível superior, enquanto que as faculdades executam atividades ligadas somente ao ensino.

Retornando ao Estatuto, este determinou que deveria incluir na organização da universidade, uma faculdade de educação, ciências e letras com a finalidade de formação de profissionais para o magistério. Essa preocupação espelha o momento histórico do país, devido ao aumento da demanda por mais escolas, e a inexistência do magistério secundário.

A criação de uma faculdade de educação tinha por finalidade torná-la um centro de formação de professores para o ensino secundário. Este projeto não se realizou efetivamente uma vez que se contrapunham diferentes modelos de universidade nesse momento. Os primeiros cursos de formação de professores, em instituições de nível superior surgiram no Brasil nos anos 30. (Candau, 1987, p.11)

Em 1937, a Universidade do Rio de Janeiro muda seu nome para Universidade do Brasil. Nesse período ainda discutia-se o papel da universidade, a função a ela conferida de: "abrigar a ciência, os cientistas e as humanidades em geral, promovendo a pesquisa". Sampaio (2000, p.68).

No período do Estado Novo devido à instabilidade da política de Getúlio Vargas - 1937 - 1945, é promulgada uma nova Constituição, com a necessidade de atender o mercado e a escassez de mão de obra especializada. Dentre as propostas estão o ensino livre à iniciativa individual e à associação ou pessoas coletivas, públicas e particulares, tirando do Estado o dever da Educação. (Sampaio, 2000). Deste modo, o governo getulista tenta, de alguma forma, atender aos interesses da indústria.

Com a instalação da Nova Constituição, no fim do Estado Novo, esta realidade se configura com um cunho mais democrático. Como versa Romanelli, "Com o fim do Estado Novo - 1946 - 1963, foi promulgada uma Nova Constituição de cunho liberal e democrático. Esta Nova Constituição na área da educação permitiu a União a legislar sobre Diretrizes e Bases - LDB, com o preceito que a educação é Direito de Todos". (Romanelli, 2006, p. 95)

A Constituição Federal de 1946 nos traz um marco importante na questão educacional, o preceito de que a educação é direito de todos, inspirada nos 
princípios proclamados pelos Pioneiros, no Manifesto dos Pioneiros da Educação Nova ${ }^{6}$, nos primeiros anos da década de 30 . "A educação é direito de todos e será dada no lar e na escola. Deve inspirar-se nos princípios de liberdade e nos ideais de solidariedade humana (Constituição Federal, 1946, art. 166).

Em 1962 é criado o Plano Nacional da Educação - PNE. Este plano não era um projeto de lei e sim basicamente um conjunto de metas a serem alcançadas em um prazo de oito anos. Foi criado também neste mesmo ano o Conselho Federal de Educação, constituído por uma maioria de dirigentes de instituições privadas.

Durante a década de 1970 houve um aumento significativo de matrículas no ensino superior, tanto no ensino público como no privado, porém não na mesma proporção. Segundo Sampaio (2000, p. 143) “Enquanto as matrículas do setor público registraram crescimento de $260 \%$, as matrículas do setor privado cresciam mais de 500\%." Na década seguinte - 1970 - 1980- O crescimento do setor privado foi de $311 \%$ e o setor público, de $143 \%$."

Isto significa que, o número de ingressantes nas instituições privadas de ensino superior durante o período acima mencionado tem sido maior do que nas instituições públicas. Uma das razões do crescimento do setor privado refere-se ao estímulo governamental, em especial através de medidas como o crédito estudantil, que possibilitam ao estudante vulnerável economicamente inserir-se no ensino superior.

Na mesma perspectiva Cunha ressalta que:

O setor privado cresceu através de recursos governamentais diretos, ou de projetos, como crédito educativo, modalidade de bolsas de estudos restituível, que permitia aos alunos pobres a entrada em faculdade, tendo como financiador a Caixa Econômica Federal. O setor público, por sua vez também se desenvolve, foi construído novos campi, instituído o trabalho docente em tempo integral e ampliadas linhas de pesquisa científica. (Cunha 1999.p. 41)

Desta forma a década 70 foi marcada pelo crescimento desordenado no ensino superior, pois com o aumento da demanda não houve tempo para o

\footnotetext{
${ }^{6}$ O Manifesto dos Pioneiros da Educação Nova evidenciava que a nação só se tornaria grande se seguisse, incondicionalmente princípios de uma educação voltada para a vida, para o trabalho moderno para o homem contemporâneo, para uma nova divisão social do trabalho. No manifesto estariam as diretrizes para esse crescimento, para uma nova construção hierárquica da sociedade. Ver Manifesto dos Pioneiros da Escola Nova de 1932. A reconstrução educacional no Brasil : ao povo e ao governo. In. AZEVEDO, Fernando. A educação entre dois mundos. São Paulo. Companhia Editora Nacional.
} 
planejamento racional da expansão, consequentemente o Estado incentivou a formação de instituições de ensino superior privadas para atendimento dessa demanda.

O contexto histórico da época era o regime militar e o estado restringia o seu papel de fiscalizador das instituições de ensino superior. Alguns educadores na época como Florestan Fernandes, Paulo Freire, entre outros desenvolviam debates ideológicos em defesa da educação e da escola pública. Da mesma forma para Teixeira, ${ }^{7}$ a educação superior deveria ser

\begin{abstract}
Obrigatória, gratuita e universal, a educação só poderia ser ministrada pelo estado. Impossível deixá-la confiada a particulares, pois estes somente podiam oferecê-la aos que tivessem posses, e daí operar antes para perpetuar as desigualdades socais, que para removê-las. A escola pública comum a todos, não seria, assim, o instrumento de benevolência de uma classe dominante, tomada de generosidade ou de medo, mas um direito do povo, sobre tudo das classes trabalhadoras. (Teixeira, 1957, p. 80)
\end{abstract}

O autor nos mostra que a busca pela equidade do direito a educação é algo que fazia parte dos debates, mas a efetividade ao direito a educação só ganhou o status de direito com a promulgação da Constituição Federal - CF de 1988. Assim sendo, a educação ganha a sua efetividade e passa a ser apreendida como direito de todos e dever do Estado. Deste modo, podemos denominar a Constituição Federal de 1988 como uma "nova fase" da educação no Brasil, pois é nela que temos a idéia clara da definição de competências, a família e o Estado são chamados à responsabilidade:

A educação, direito de todos e dever do estado e da família, será promovida e incentivada com a colaboração da sociedade, visando ao pleno desenvolvimento da pessoa, preparo para o exercício da cidadania e sua qualificação para o trabalho. (Constituição Federal, 1988, art. 205)

As políticas universais preconizadas na Constituição Federal de 1988, em especial a política de educação não têm alcançado efetivamente este propósito. O resultado disso é uma disparidade social que atinge de forma perversa uma parcela considerável da população brasileira. Os dados a seguir demonstram

\footnotetext{
${ }^{7}$ Anísio Teixeira teve importante papel na educação do Brasil, em 1931, atuava junto ao Ministério da educação e saúde, dedicava-se à tarefa de reorganizar o ensino secundário. Fundou a UDF, do Rio de janeiro. Era um dos signatários do Manifesto dos Pioneiros da Escola Nova, documento que defendia uma escola pública gratuita, laica e obrigatória. Em contrapartida, sofreu forte oposição da igreja católica, cujo projeto educacional era calcado em pressupostos inteiramente diferentes dos que ele apregoava.
} 
que 3,8 milhões crianças e adolescentes entre 4 e 17 anos estão fora da escola. Os dados revelam que o Brasil não atingiu em 2010 a meta no ano de que era de $93,4 \%$ de acesso. A taxa de inclusão ficou em $91,5 \%$ do total de jovens com idade escolar ${ }^{8}$.

Diante disso, podemos afirmar que o principal meio de se modificar tal situação é fazer com que as políticas públicas brasileiras assumam de fato seu caráter igualitário. Acredita-se que, por meio das instituições educacionais públicas, com ensino universal e de qualidade, pode-se construir uma sociedade menos desigual.

Outro aspecto importante refere-se ao acesso e permanência na escola, através das concepções de igualdade, liberdade e pluralismo no ensino. Foram contemplados na CF dispositivos voltados para a busca da qualidade do ensino e a garantia das condições de trabalho dos profissionais da educação. Conforme o disposto no art. 206:

\footnotetext{
O ensino será ministrado com base nos seguintes princípios:

I - igualdade de condições para o acesso e permanência na escola;

II - liberdade de aprender, ensinar, pesquisar e divulgar o pensamento, a arte e o saber;

III - pluralismo de idéias e de concepções pedagógicas, e coexistência de instituições públicas e privadas de ensino;

IV - gratuidade do ensino público em estabelecimentos oficiais;

V - valorização dos profissionais da educação escolar, garantidos, na forma da lei, planos de carreira, com ingresso exclusivamente por concurso público de provas e títulos, aos das redes públicas;

$\mathrm{VI}$ - gestão democrática do ensino público, na forma da lei;

VII - garantia de padrão de qualidade;

VIII - piso salarial profissional nacional para os profissionais da educação escolar pública, nos termos de lei federal.
}

Chamamos a atenção quanto ao inciso primeiro, pois este se refere à premissa de igualdade de condições de acesso e permanência na escola, fato que não tem ocorrido em nosso cotidiano. Estatísticas do Instituto Nacional de Estudos e Pesquisas Educacionais Anísio Teixeira - INEP apontam que em 2005 no Brasil havia 25 milhões de jovens com faixa etária entre 18 e 24 anos que não ingressaram no ensino superior mesmo tendo concluído o ensino médio (INEP - 2005).

Neste sentido Silva (2011), traz uma importante reflexão sobre o conceito de equidade. Na concepção do autor, a equidade garante a justiça visto que apresenta a noção de acesso diferente para aqueles que possuem condições

\footnotetext{
${ }^{8}$ Dados obtidos pelo site www.todospelaeducação.org.br, - Deed//Inep/MEC (2010).
} 
diferentes. Já igualdade para o autor não garante a justiça, já que apresenta igualdade de condições para os que possuem um "ponto de partida" desigual.

Hoje, a noção de igualdade é profundamente discutida, pois a igualdade de condições para quem tem condições diferentes é algo que consagra a injustiça. Em seu lugar, há um movimento em defesa de outro conceito, o de equidade, o que significa o oferecimento de condições de acesso e permanência diferentes para quem tem condições diferentes. (Pablo Silva, 2011.p.17)

Em se tratando das diferenças de condições na questão do acesso e permanência na educação, as políticas afirmativas, ${ }^{9}$ podem ser apreendidas como uma resposta a estas exigências. "As políticas de viés afirmativas são uma resposta às exigências feitas por grupos sociais como negros, mulheres, homossexuais, entre outros, por direitos coletivos e culturais" (Clapp, 2010.p.138).

Lourenço (2009, p. 27) corrobora com a ideia da autora acima mencionada quando afirma que "podemos entender as Ações Afirmativas como instrumentos que têm como finalidade a promoção da igualdade e a universalização concreta dos direitos em certa sociedade." Deste modo às políticas afirmativas podem ser reconhecidas como políticas de reconhecimento.

As políticas de reconhecimento estariam voltadas para a redução das desigualdades sociais, baseados em aspectos identitários e culturais. [...]. A igualdade efetiva só ocorrerá quando as diferenças forem reconhecidas. (CLAPP, 2010 p.137 e 151)

A autora acrescenta ainda que a solução para este tipo de desigualdades estaria nas políticas de reconhecimento, voltadas para o respeito e garantia do que diferenciam. (p.141). Entendemos, portanto, que é na política de reconhecimento que estão intrínsecas as políticas afirmativas.

Retornando a questão do acesso e a permanência na educação, entendese que estes dois caminham lado a lado, assim como a necessidade do ser

\footnotetext{
9 Joaquim Barbosa Gomes define ação afirmativa sendo um conjunto de políticas públicas e privadas de caráter compulsório, facultativo ou voluntário, concebidas com vista ao combate a discriminação racial, de gênero, por deficiência física e de origem nacional, bem como para corrigir ou mitigar os efeitos prescritos da discriminação praticada no passado, tendo por objetivo a concretização do ideal de efetiva igualdade de acesso a bens fundamentais como a educação e o emprego.(p.27).
} 
humano de estar pronto para adquirir novos conhecimentos, Freire (1997)

${ }^{10}$ afirma:

A educação é uma busca realizada pelo homem, tem caráter permanente, pois ele é um ser inacabado. Desta forma, ele não possui saber de maneira absoluta, havendo necessidade de estarmos nos educando sempre, através da superação constante das diferentes formas de saber. (p.14)

Desta forma entende-se que a educação deve ser considerada como um direito universal, que pressupõe a igualdade de condições tanto para o acesso quanto para a permanência, fato que não vem se consolidando na rotina das universidades. Pode-se se dizer que a universalização do direito a educação não vem se consolidando conforme preconizado na Lei.

$\mathrm{E}$, ainda mais, constata-se diante das sucessivas Constituições Brasileiras que proclamaram o direito de todos à educação, observa-se que existe uma diferença entre o direito proclamado e o direito efetivamente desfrutado.

\begin{abstract}
Uma coisa é proclamar esse direito outro é desfrutá-lo efetivamente. A linguagem dos direitos tem indubitavelmente uma grande função prática, que é emprestar uma força particular às reivindicações dos movimentos que demandam para si e para os outros a satisfação de novos carecimentos materiais e morais; mas ela se torna enganadora se obscurecer ou ocultar a diferença entre o direito reivindicado e o direito reconhecido e protegido. (Bobbio, 1992 p.10)
\end{abstract}

É necessário garantir, assegurar e proteger os direitos mais do que fundamentá-los através de medidas que garantam e protejam tais direitos. "O importante não é fundamentar os direitos do homem, mas protegê-los.". (Bobbio, 1992).

Retornando ao cenário histórico do ensino superior, em 1990, início do processo de ajuste neoliberal ${ }^{11}$ no Brasil, as ideias propostas pelo consenso de Washington ${ }^{12}$, definem um conjunto de ideias e propostas neoliberais também voltadas à intervenção na educação.

\footnotetext{
${ }^{10}$ PUC-Rio - Certificado Digital n. 0610369/CA- Ensino Superior e pobreza em tempos neoliberais: algumas reflexões.

${ }_{11}$ As políticas neoliberais foram preconizadas na economia brasileira por instituições internacionais, como o Fundo Monetário Internacional (FMI), o Banco Interamericano de Desenvolvimento (BID) e o Banco Mundial, por meio de reformas que resultaram em uma redução do Estado em prover a proteção e a garantia dos direitos, impondo "uma contraditória convivência entre universalização e seletividade, bem como o suporte legal ao setor privado, em que pese a caracterização de dever do Estado para algumas políticas, com nítida sustentação de cunho conservador". Behring e Boschetti (2007, p. 145)

${ }^{12} \mathrm{O}$ Consenso de Washington foi um conjunto de medidas composto de 10 regras básicas elaborado por instituições como FMI, Banco Mundial e o Departamento do Tesouro dos Estados
} 
Questões como a necessidade de constituir estruturas de controle e avaliação da qualidade dos serviços no setor de educação - de maneira geral no campo do aparelho educacional, e de maneira específica, dentro das instituições educacionais - e a necessidade de submeter à educação às normas estabelecidas pelo mercado de trabalho, dão coerência às reformas educacionais implementadas pelos governos neoliberais. (Gentili. 1998.p.24)

Gentili afirma ainda, que os pontos acima elencados podem significar o fortalecimento do sistema meritocrático no interior das instituições educacionais uma vez que

O primeiro materializa e garante os princípios meritocráticos e competitivos. O segundo dá sentido e estabelece o rumo (o horizonte) das políticas educacionais, ao mesmo tempo em que permite estabelecer critérios para avaliar a pertinência das propostas de reforma escolar. É o mercado de trabalho quem emite os sinais que permitem orientar as decisões em matéria de política educacional. É avaliação das instituições escolares e o estabelecimento de rigorosos critérios de qualidade o que permite dinamizar o sistema através de uma lógica de prêmios e castigos que estimulam a produtividade e a eficiência. (Gentili.1998.p.24-25)

Neste sentido, Gentili faz duas observações relevantes, no que se refere às idéias do neoliberalismo no campo educacional e o perverso resultado dessas proposições quando afirma

O neoliberalismo formula um conceito específico de qualidade (grifo do autor), decorrente das práticas empresariais e transferido, sem mediações, para o campo educacional. As instituições escolares devem ser pensadas e avaliadas (isto é, devem ser julgados seus resultados) como se fossem empresas produtivas.Produz-se nelas um tipo específico de mercadoria( o conhecimento, o aluno escolarizado, o currículo) e, conseqüentemente, suas práticas devem estar submetidas aos mesmos critérios de avaliação que se aplicam em toda empresa. $O$ neoliberalismo enfatiza que a educação deve estar subordinada às necessidades do mercado de trabalho, isto é, de que o sistema educacional se ajuste às demandas do mundo dos empregos. Isto não significa garantir esse emprego, pelo contrário, o sistema educacional deve promover a empregabilidade, que é a capacidade flexível de adaptação individual às demandas do mercado de trabalho. (Gentili,1998.p.26)

Concorda-se com a afirmação do autor, de fato, tem-se hoje um sistema educacional que muitas vezes, volta-se para a profissionalização, para atender

Unidos em 1990. A princípio a fim de orientar o desenvolvimento econômico de países da América Latina e aceito e seguido sem muito questionamento por estes países em troca de empréstimos financeiros, Essas medidas neoliberais favoreciam especulação financeira dos capitalistas que forneciam o dinheiro emprestado, ou seja, escravizava economicamente os países emergentes. A este respeito ver: SARMENTO, Dira Chaves. Qual educação para que país. In: SARMENTO, Dira Chaves (org.) Sistemas de Educação no Brasil: Políticas, autonomia e cooperação. Juiz de Fora: Editora UFJF, 2010. 
as exigências impostas pelo capital, que absorve "os melhores, os mais bem preparados". O ensino superior apresenta-se como uma ferramenta para subsidiar carreiras profissionais, focando apenas no ensino, sem preocupar-se com a pesquisa e a extensão.

Para Gentili a função "social" da educação esgota-se neste ponto.

Ela encontra o seu preciso limite no exato momento em que um indivíduo se lança ao mercado para lutar por um emprego. A educação oferece as ferramentas necessárias para competir nesse mercado. $O$ restante depende das pessoas, alguns triunfarão e outros condenados ao fracasso. (Gentili,1998p.26).

O neoliberalismo reproduz os privilégios das elites, exacerbam o individualismo e a competição selvagem, quebrando assim os laços de solidariedade coletiva e intensificam um processo antidemocrático e de seleção "natural" onde os "melhores" triunfam e os "piores" perdem. E em nossa sociedade os "melhores" acabam sendo as elites que monopolizam o poder político, econômico e cultural. (Gentili, 1998)

Tendo em vista o contexto neoliberal, e a sua implementação na área educacional, a Lei de Diretrizes e Bases da Educação (Lei n. 9394/96), contribui com aspectos importantes para a implementação do ajuste neoliberal tais como: credenciamento das instituições de ensino superior; avaliação periódica; dissociação do tripé do ensino superior (ensino, pesquisa e extensão), que passa a ser obrigatório somente para as universidades.

Com a implantação da LDB, houve aceleração no acesso ao ensino superior, principalmente durante a segunda metade dos anos 1990. Tal expansão ocorreu em maior intensidade no setor privado. Essa reforma universitária instaurada naquele período foi mantida no início dos anos 2000, através da instalação pelo Governo Federal de um grupo de trabalho - GT interministerial, para analisar a situação do ensino superior. Este GT apresentou um plano de ação para as Instituições de Ensino Superior - IES e apontou algumas questões tais como, a necessidade de ampliação de vagas e aumento do quadro de docentes; dá ênfase no ensino à distância como forma de ampliação do ensino superior público, e ainda, destaca a autonomia universitária, principalmente, no tocante a autonomia financeira.

A partir de 2001, o Governo Federal aprovou o Plano Nacional da Educação - PNE, que estabelece diretrizes para a implementação de ações para a educação. O PNE é um documento que responde aos compromissos firmados 
pelo Brasil, através de assinatura de declarações em conferências internacionais sobre educação. Neste documento verifica-se a expansão do setor privado e a demanda por educação para alunos oriundos da população pobre concluintes do ensino médio publico. Neste sentido, até o final da primeira década do século XXI, este plano estabelece uma meta de que pelo menos $30 \%$ da faixa etária de 18 a 24 anos da população brasileira estejam no ensino superior. Almeida, (2006, p.56).

Para que o Governo Federal pudesse atingir essa meta, instituiu em 2005 - Programa Universidade para Todos - ProUni que permite o acesso deste público no ensino superior privado. O ProUni é um programa desenvolvido pelo Ministério de Educação, no âmbito federal. Consiste na concessão de bolsas de estudo, integral ou parcial em instituições de ensino privados, teve início em 2004, regulamentado pela Lei n. 11. 096 de 13 de janeiro de 2005. Este programa tem o objetivo de promover o acesso de jovens de baixa renda ao ensino superior privado.

Já, em 2007, através do Decreto 6.096 de 24 de abril, foi instituído o Programa de Apoio aos Planos de Reestruturação e Expansão das Universidades Federais - REUNI. Cabe esclarecer que o REUNI, enquanto política pública de educação recente tem como objetivo criar condições para ampliação do acesso e permanência na educação superior, pelo melhor aproveitamento da estrutura física e de recursos humanos existentes nas Universidades Federais. Para que esse objetivo seja alcançado, o governo propõe algumas diretrizes: reduzir a taxa de evasão; ocupar vagas ociosas, aumentar as vagas de ingresso; ampliar a mobilidade acadêmica; ampliar as políticas de inclusão social e assistência estudantil.

Para Mancebo (2008, p. 01) a reforma universitária deveria ser composta para medidas que suprissem a necessidade de ampliação da rede de ensino superior, sem afetar, gastos ä União. Contudo, entende-se que a partir do momento que o governo federal libera as universidades particulares de pagamento de impostos, renunciando o valor fiscal em troca da participação destas na liberação de vagas, preceitos do ProUni, o governo federal além de transferir suas responsabilidades com a educação, conforme é preconizado na Constituição, deixa de arrecadar seus impostos nessa negociação.

Dentre das demais propostas desenvolvidas pelo PNE destacamos a questão da redução das desigualdades sociais através de políticas de democratização do ensino público e de políticas de acesso e permanência no ensino superior. Apesar da política neoliberal adotada nos últimos anos, 
percebe-se que houve avanços significativos na última década no tocante à defesa da garantia dos direitos à educação e a sua efetividade em termos de garantia de acesso, permanência e qualidade de ensino superior.

No que diz respeito ao processo de ingresso através do exame de vestibular e do acesso diferenciado, podemos identificar que um número significativo de universidades brasileiras tem adotado políticas ou programas de ações afirmativas ${ }^{13}$. O trabalho apresentado por Machado e Silva no ano de 2010, já aponta esta tendência. Vejamos:

\begin{abstract}
A adoção das políticas de ação afirmativa tem sido implantada na maioria das IFES, com poucas exceções, como Rondônia e Acre. Ou seja, das 27 IFES nos dias atuais, apenas duas não possuem universidades com ação afirmativa. De um total de 94 universidades públicas (estaduais ou federais) brasileiras, 65 , ou $70 \%$ do total de universidades públicas, possuem no concurso vestibular algum tipo de acesso diferenciado para os candidatos às vagas dos cursos de graduação. (Machado e Silva, 2010. p.27.)
\end{abstract}

No que tange os tipos diferenciados de acesso, Paiva (2010) refere-se que há uma diversidade de nomenclaturas utilizadas nos editais de exames de vestibulares. Esta diversidade de nomenclaturas, no entendimento da autora pode ser apreendida como modalidades distintas de implementação da política de ação afirmativa.

\begin{abstract}
Há uma grande diversidade de nomenclaturas sobre a temática que define os programas de ação afirmativa, são elas: Cotas: são aquelas que têm como princípio o estabelecimento de porcentagem ou quantidade fixa no número total de vagas oferecidas; Acréscimo de vagas: quando são criadas vagas fora do modelo tradicional de edital. Geralmente são quantidades fixas, mas podem ser feitas com porcentagens; Acréscimo de notas: quando são acrescidos pontos a mais para o candidato, podendo ser pontos fixos ou porcentagem. (Paiva, 2010.p.29)
\end{abstract}

Desta forma, entendemos que não importa o tipo de nomenclatura que está sendo adotada pelas universidades, mas sim, o fato de que a democratização do acesso já pode ser considerada uma realidade. A partir disso, um novo perfil de estudantes está se agregando aos bancos das universidades. O que demanda uma releitura do papel social da universidade.

Quando mencionamos especificamente políticas de permanência do estudante, estamos falando em garantir a fixação do estudante na universidade

\footnotetext{
${ }^{13}$ A este respeito ver: MACHADO, Elielma Ayres \& SILVA, Fernando Pinheiro . Ações Afirmativas nas Universidades Públicas: $O$ que dizem os editais e manuais. In: PAIVA. Ângela Randopho. Entre dados e fatos: Ação Afirmativa nas Universidades Públicas Brasileiras. Rio de Janeiro. PUCRio, Pallas Ed. 2010.
} 
e que este possa concluir o curso com sucesso e qualidade, reduzindo o percentual de evasão e o desperdício do dinheiro público. Para que isto realmente se concretize, precisamos saber de que universidade está se falando e qual é o seu papel social e qual é o seu projeto político-pedagógico.

\title{
1.2.
}

\section{O Papel Social da Universidade}

Qual é a função das universidades enquanto instituição social? $\mathrm{Na}$ tentativa de responder esta questão cabe ressaltar as palavras de Anísio Teixeira: "A Universidade é a casa onde se acolhe toda a nossa sede de saber e toda a nossa sede de melhorar, é um espaço privilegiado no qual o conhecimento nasce ou se revigora." (1962, p. 183). Assim sendo, a universidade deve ser o local de aprendizado, o local onde os diversos saberes se encontram, tornando-se um local de discussão e debates.

Este papel em nosso entendimento vai além do tripé ensino-pesquisaextensão. Ou seja, o conhecimento adquirido e produzido deve, de certa maneira, ser revertido para a sociedade. O estudante após passar pela universidade adquire uma responsabilidade maior, adquire a responsabilidade de compartilhar o que foi vivenciado. Nesta perspectiva, Anísio Teixeira (1988) afirma que a função da universidade é única e exclusiva:

\begin{abstract}
A função da universidade não se trata, somente, de difundir conhecimentos. O livro também os difunde. Não se trata, somente, de conservar a experiência humana. O livro também conserva. Não se trata, somente, de preparar práticos ou profissionais, de ofícios ou artes. A aprendizagem direta os prepara, ou, em último caso, as escolas muito mais singelas do que as universidades. Trata-se de manter uma atmosfera de saber pelo saber para se preparar o homem que o serve e o desenvolve. Trata-se de conservar o saber vivo e não morto, nos livros ou no empirismo das práticas não intelectualizadas. Trata-se de formular intelectualmente a experiência humana, sempre renovada, para que a mesma se torne consciente e progressiva. (p.18)
\end{abstract}

Com essas palavras o autor chama atenção para uma das características da universidade, que ela seja "um locus de investigação e produção de conhecimento". (1988, p.17 e 18). Portanto, a universidade não deve ser 
apreendida como algo a parte da sociedade, mas sim como uma espécie de autorretrato do momento histórico e social vivenciado. Assim sendo, a universidade reflete a sociedade a qual está inserida. Deste modo, estar dentro do ambiente universitário, deve significar estar inserido no contexto da sociedade contemporânea.

Ainda sobre esta questão, Chauí (2001) expressa a importância da universidade na sociedade e sua representatividade, afirmando que ela não está desvinculada das relações políticas, sociais e culturais. A autora versa que a universidade inverteu seu sentido e finalidade "em lugar de criar elites dirigentes, está destinada a adestrar mão-de-obra dócil para o mercado sempre incerto". (2001, p.46). A autora segue com sua reflexão ao afirmar que hoje a universidade

Cria incompetentes sociais e políticos, realiza com a cultura o que a empresa realiza com o trabalho, isto é, parcelar, fragmentar, limitar o conhecimento e impedir o pensamento, de modo, a bloquear toda tentativa concreta de decisão, controle e participação, tanto no plano da produção material quanto no da produção intelectual. ( 2001, p.46)

Neste contexto, a universidade adapta-se às necessidades do mercado em um estado neoliberal e assim o papel da universidade e da educação se redefine:

\begin{abstract}
Neoliberal porque se orienta não mais para as necessidades da nação, mas para as exigências do mercado; porque se vê como um empreendimento como tantos outros, sendo preferível que sua iniciativa seja privada, não pública; porque sua administração deve atender antes aos requisitos da eficiência gerencial do que aos reclamos da participação política; porque não se vê mais como uma instituição que tem um compromisso para melhorar a vida social, deixando questões como essa ao livre jogo das forças do mercado; e, enfim, neoliberal, porque passa a se definir como um espaço onde o indivíduo busca instrumentos para o seu sucesso na sociedade e não onde a sociedade habilita indivíduos para seu serviço. (Castanho, 2000, p. 36).
\end{abstract}

Não basta o universitário ter apenas habilidades técnicas e/ou comportamentais, é preciso estar qualificado para o mercado, que por sua vez é injusto, competitivo e excludente. Ao trabalhador é exigida a polivalência, a multifuncionalidade para continuar inserido e adaptado no mercado de trabalho capitalista. 
A atual tendência dos mercados de trabalho é reduzir o número de trabalhadores centrais e empregar cada vez uma força de trabalho que entra facilmente e é demitida sem custos. Neste contexto, os trabalhadores excluídos do trabalho estável são incluídos no trabalho informal de forma precária e desprotegida correndo o risco do desemprego permanente. (Antunes 2007. p .54)

A educação desvinculou-se do saber e a universidade revela assim que a sua tarefa não é produzir e transmitir cultura, mas treinar os indivíduos a fim de que sejam produtivos para quem for contratá-los. "A universidade adestra mãode-obra e fornece força de trabalho". (Chauí, 2001, p.52). Ultimamente a "política tem sido a de imprimir uma lógica mercantil e empresarial à universidade brasileira [...] segundo o que Chauí denomina "Universidade Operacional" ou "Universidade de Serviços"”. (Chauí, 1999 apud Iamamoto, 2008, p. 433).

Neste ponto entende-se que a universidade perdeu a sua principal função: a de desenvolver o conhecimento e o saber. Em troca ela está preparando os indivíduos para que sejam produtivos para cumprir as exigências do mercado de trabalho. Desta forma, pode-se supor que a universidade articulada e representada na figura do Estado e comprometida com o capital, fornece à sociedade mão-de-obra para o mercado de trabalho, "substituindo assim o conceito de educação como direito pelo de serviços, que leva e coloca os direitos como a saúde, a educação e a cultura no setor de serviços estatais, destinados a se tornar não estatais". (Chauí, 2001. p.177).

Assim, o espaço público dos direitos é desprestigiado e o espaço privado é ampliado, justamente no campo dos direitos sociais conquistados. O estado se desobriga de uma atividade eminentemente política, uma vez que pretende desfazer a articulação democrática entre poder e direito. Ao colocar a educação no campo de serviços, O estado deixa de considerá-la um direito dos cidadãos e passa a tratá-la como qualquer outro serviço público que pode ser terceirizado ou privatizado. "A universidade tem que ser defendida como um espaço público (grifo da autora) porque a universidade é o lugar da opinião livre, que dá o direito da sociedade o direito à produção do saber e da cultura" (Chauí 2001.p.67).

Chauí e Bernheim (2008. p.20) consideram que a educação superior é um fenômeno de alta complexidade e a sua tarefa precisa ter relevância social nos sistemas de educação superior e devem enfatizar uma relação dialética com a sociedade. Neste sentido, a Declaração Mundial sobre Educação Superior para 


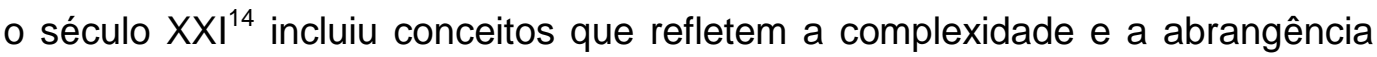
da missão social da educação superior contemporânea:

a) a educação superior deve ser avaliada em função da adequação entre a que a sociedade espera das instituições e o que estas fazem. Isto exige padrões éticos, imparcialidade política, capacidade critica e , ao mesmo tempo, melhor articulação com os problemas da sociedade e do mundo do trabalho, baseando as orientações de longo prazo em objetivos e necessidades societais, compreendidos o respeito pelas culturas e a proteção ambiental. A preocupação é de abrir acesso tanto à educação geral ampla como à educação especializada, especifica para determinadas carreiras, muitas vezes interdisciplinar, centrada nas competências e aptidões, pois ambas preparam os indivíduos a viver em situações diversas e a poder mudar de ocupação.

b) A educação superior deve reforçar seu papel de prestadora de serviço à sociedade, especialmente orientada a erradicar a pobreza, a intolerância, a violência, o analfabetismo, a fome, a doença e a degradação ambiental, sobretudo mediante uma abordagem interdisciplinar e transdisciplinar na analise dos problemas e das questões.

c) A educação superior deve fortalecer sua contribuição ao desenvolvimento de todo o sistema educacional, sobretudo para o aperfeiçoamento dos docentes, do desenvolvimento curricular e da pesquisa educacional.

d) Finalmente, a educação superior deve visar à criação de uma sociedade, não violenta e não exploradora formada por indivíduos altamente esclarecidos, motivados e integrados, inspirados pelo amor à humanidade e guiados pela sabedoria. (Chauí e Bernheim, 2008.p.21)

Desta forma, a universidade deve ter seu compromisso com a transformação da sociedade, com exercício da critica livre, com a preservação do conhecimento, com a construção de um novo saber, baseados em valores da ética da democracia, da justiça e da equidade.

$\mathrm{Na}$ discussão sobre o papel da universidade do século XXI vem à tona a questão da inclusão social, um dos pilares da política para educação superior e pode-se entender que existe hoje uma falta de sintonia entre a sociedade e a universidade.

Neste contexto, Santos (2004) aponta quatro papéis importantes e fundamentais da universidade do futuro, uma vez que "ela tem de ser vanguarda na produção do conhecimento, vanguarda na distribuição do conhecimento, vanguarda no futuro dos alunos e vanguarda na conquista de um país mais justo, e menos excludente". O autor acrescenta ainda que existem outras

${ }^{14}$ Declaração Mundial sobre Educação Superior para o século XXI: Visão e Ação Conferência Mundial sobre Educação Superior - UNESCO, Paris, 9 de outubro de 1998. 
questões importantes relacionadas à universidade que são: "Aumento do número de ingressos nas universidades e a democratização do acesso, ensino à distância, interiorização da universidade, discussão das cotas e o combate às vagas ociosas, remanescentes e a evasão estudantil." (2004, p. 58)

Com relação às vagas ociosas e a evasão universitária, entendemos que cada universidade deve ter ciência do que significa uma vaga ociosa, considerando as dificuldades pelas quais passa o estudante quando pretende ingressar no ensino superior público. E de tal modo, para o combate a evasão estudantil cada IFES deverá propor estratégias para a assistência ao estudante.

Panizzi (2004) reconhece nesta questão que não basta aumentar o número de vagas ou simplesmente combater os problemas da evasão. Para a autora a democratização do acesso significa que,

A universidade pública deverá abrir mais e mais para uma população carente de recursos financeiros, que precisa de apoio no plano da moradia, da alimentação e mesmo da renda, através de bolsas e de outras formas de auxilio. Assim o debate sobre políticas de assistência estudantil não pode ser mais adiado (Panizzi, 2004 p. 67).

Concorda-se com a fala da autora, uma vez que, hoje é fundamental que a universidade busque alternativas que viabilizem a manutenção do estudante vulnerável economicamente, por meio de políticas específicas que garantam o acesso e em especial a permanência este público. ${ }^{15}$

Boaventura de Sousa Santos (2004) aponta que para uma universidade ser uma Universidade é necessário que ela seja realmente definida, pois muito se tem chamado de "universidade" aquilo que na realidade não é.

Isto foi possível devido à acumulação indiscriminada de funções atribuídas à universidade ao longo do século XX. Como elas foram adicionadas sem articulação lógica, o mercado do ensino superior pôde auto-designar o seu produto como universidade sem ter de assumir todas as funções desta, seleccionando as que se the afiguraram fonte de lucro e concentrando-se nelas [...] no século XXI só há universidade quando há formação graduada e pósgraduada, pesquisa e extensão. Sem qualquer destes, há ensino superior, não há universidade. (Sousa Santos, 2004 p. 64).

Considera-se fundamental que a universidade deve atender ao tripé ensino-pesquisa-extensão, por meio do ensino de graduação e de pósgraduação, da pesquisa e de ações de extensão universitária, pela integração e

\footnotetext{
${ }^{15}$ Abordaremos a questão da Política Nacional de Assistência Estudantil no decorrer deste trabalho.
} 
articulação desses segmentos. Assim, por ser patrimônio da sociedade, a universidade pública, em especial, deve oferecer respostas concretas a essa sociedade, por meio das pesquisas e dos debates que visem melhorar a qualidade de vida não apenas do estudante, mas também de seu corpo docente e técnico. Entende-se que a universidade é um espaço de lutas e de discussões. É o local que se faz refletir a sociedade e as contradições que nela refletem.

A Universidade é o laboratório onde é possível construir experiências de convívio social mais avançada. [...] Uma nação precisa da universidade. Não há nação sem a inclusão social - sem ela o processo é de barbárie, é de desconstrução dos próprios fundamentos da nação [...]. (Lessa, 2004, p.43)

Esse conceito apresentado por Lessa demarca a forma contraditória como a universidade brasileira foi constituída. Influenciada pelo pensamento liberal e pelo pensamento autoritário dos interesses das classes dominantes, a universidade foi criada para servir a estes setores e não para atender às demandas postas pela sociedade.

Assim, refletir sobre o papel social que cumpre à universidade no século XXI por meio do ensino, pesquisa e extensão, perpassa o espaço que a Educação Superior ocupa na sociedade contemporânea, sua relação com a construção e adoção de políticas públicas, além de toda a complexidade da constituição dos sujeitos. E para tal faz-se necessário buscar diferentes frentes de atuação.

\footnotetext{
Estabelecer estratégias políticas e mecanismos institucionais que possam contribuir para a construção de um olhar da e sobre a Universidade, favorecendo, assim, a redefinição do papel político, social, cultural e epistemológico da universidade na sociedade no qual extensão, pesquisa e ensino sejam vistos e vivenciados, de forma indissociável, como espaços de produção de conhecimento legitimados. (Moehlecke, ano p.6)
}

Ainda Boaventura de Sousa Santos (2010, p.3) a Universidade ocupa um espaço complexo uma vez que:

Ao mesmo tempo fortalece as relações sociais e é vanguarda no desenvolvimento técnico-científico e informacional; retroalimenta a sociedade ao formar o homem para o mundo do trabalho ao tempo em que é palco para discussão das questões relacionadas à sua própria formação e à (con) formação da sociedade. (Sousa Santos, 2010), p.3). 
Nesse espaço múltiplo e singular, políticas afirmativas de acesso e permanência na educação superior têm sido implantadas no Brasil, na primeira década do Século XXI, a partir das Universidades Públicas, como uma tentativa de estabelecer igualdade de direitos e oportunidades para contribuir com a diminuição das desigualdades socioeconômicas no país.

As primeiras iniciativas observadas tratam 0 assunto como ações reparadoras e consideram 0 acesso por meio de cotas destinadas exclusivamente a candidatos com vulnerabilidade socioeconômica, egressos de escolas públicas, de origem negra ou o oferecimento de bônus na pontuação em seus processos de vestibulares ${ }^{16}$.

E para garantir a permanência desses estudantes na universidade, são implementadas ações voltadas para a manutenção dos estudantes definidos pelo Programa Nacional de Assistência Estudantil - PNAES ${ }^{17}$, que tem como objetivo viabilizar a igualdade de oportunidades entre todos os estudantes e contribuir para a melhoria do desempenho acadêmico, a partir de medidas que buscam combater situações de repetência e evasão.

\section{3.}

\section{A Evasão no Ensino Superior}

A evasão é um fenômeno complexo, resultante de uma conjunção de fatores que pesam na decisão do estudante de permanecer ou não no curso. Segundo o INEP (2009), o número de concluintes no ano de 2009 foi menos de $20 \%$ do número de ingressantes no ensino superior, o que significa que embora se concorde que houve avanços quando se reflete sobre a expansão de vagas no ensino superior, ainda há muitos estudantes que embora acessem a universidade, não conseguem concluir seus estudos.

\footnotetext{
${ }^{16}$ Dizem-se cotas ou acréscimo de bônus as categorias utilizadas para definir as formas de ação afirmativa. Para maiores informações ver: MACHADO, Elielma Ayres \& SILVA, Fernando Pinheiro. . Ações Afirmativas nas Universidades Públicas: O que dizem os editais e manuais. In: PAIVA. Ângela Randopho. Entre dados e fatos: Ação Afirmativa nas Universidades Públicas Brasileiras. Rio de Janeiro. PUC-Rio, Pallas Ed. 2010.

17 Programa Nacional de Assistência Estudantil- A este respeito ver: Decreto № 7.234, de19 de julho de 2010. Dispõe sobre o Programa Nacional de Assistência Estudantil - PNAES.
} 
A busca pelas causas da evasão no ensino superior tem sido objeto de muitos trabalhos e pesquisas educacionais, como de Hoffmann (1993/1994), Bardagi \& Hutz (2005), Durham (1997), dentre outros estudiosos. Estes estudos apontam que a evasão é um fenômeno que envolve várias questões que podem ser de caráter financeiro, aspectos didático-pedagógicos e à infraestrutura dos estabelecimentos de ensino superior, são fatores que podem influenciar na decisão do estudante evadir da universidade ou do curso. Para a UNESCO (2006), a evasão estudantil é o processo de abandono voluntário do estudante por influência interna ou externa à universidade, em um curso ou em uma área do conhecimento.

O estudo da evasão no ensino superior brasileiro teve como marco formal em 1995, quando foi instituída a Comissão Especial para o Estudo da Evasão pela Secretaria de Educação Superior do Ministério da Educação (SeSu/MEC). Neste ano, o MEC e as Universidades Públicas Brasileiras manifestaram grande preocupação com o assunto, o que ocasionou o surgimento de um macro estudo.

Este estudo estabeleceu conceitos, indicou procedimentos com bases científicas e contribuiu para um melhor conhecimento e diagnóstico das Instituições Federais de Ensino Superior - IFES e permitiu conduzir de maneira mais objetiva e menos intuitiva, os processos de troca de experiências educacionais e definiu a evasão dos cursos de graduação como sendo a "saída definitiva do aluno de seu curso de origem, sem concluí-lo". (Comissão Especial, 1995, p.59).

Dados disponibilizados pelo INEP no ano de 2005 mostraram que entre os anos de 2000 e 2005 a média de evasões das Instituições de Ensino Superior no Brasil chegou a $22 \%$. No caso das Universidades Públicas, a média no mesmo período foi de $12 \%$, o que evidencia um grave quadro no campo da formação superior.

Em 2007 o Instituto Lobo para o Desenvolvimento da Educação, da Ciência e da Tecnologia ${ }^{18}$ publicou o trabalho "A evasão no Ensino Superior Brasileiro", no qual são apresentadas estatísticas referentes à evasão nas instituições públicas e privadas. Tal estudo concluiu que este fenômeno não se restringe apenas questões de ordem financeira. Aspectos como a integração do estudante à instituição em que estuda e as expectativas do aluno em relação à formação acadêmica também aparecem como fatores que contribuem com a evasão.

\footnotetext{
${ }^{18}$ Pesquisa- Estudo sobre Evasão no Ensino Superior Brasileiro- Instituto Lobo para o Desenvolvimento da Educação, da Ciência e da Tecnologia.
} 
Ainda contribuem para evasão a mudança de área/curso pelo estudante e a decepção no que tange às expectativas em relação à vida universitária, a estrutura e a metodologia do trabalho acadêmico.

De 2008 para 2009, um total de 896.455 estudantes abandonaram a universidade, considerando as públicas e particulares, o que representa uma média de $20,9 \%$ do universo de alunos, nas instituições públicas 114.173 estudantes (10,5\%) largaram os cursos. (Instituto Lobo,2008, p.647)

Oscar Hipólito ${ }^{19}$ ressalta que são vários motivos que levam o estudante a abandonar o ensino superior. Na concepção do pesquisador "além de os jovens terem dificuldades financeiras de se manterem durante o curso, há outro grande problema: a falta de acompanhamento acadêmico e pedagógico". (Instituto Lobo p.643). O pesquisador ressalta que nas universidades falta, além de programas de auxilio financeiro para estudantes que apresentam vulnerabilidade socioeconômica, falta também, programas de tutoria, monitoria e de acompanhamento pedagógico que possam auxiliar aqueles estudantes, principalmente os oriundos de escola pública que chegam à universidade com dificuldades no acompanhamento dos conteúdos e de aprendizagem.

Para o Professor Nelson Cardoso Amaral da Universidade Federal de Goiás - UFG em palestra organizada pela ANDIFES $^{20}$ - 2008 afirma que os estudos sobre a evasão ainda apresentam-se ineficientes no que tange suas causas: "Vários estudos apresentam diagnósticos quantitativos sobre evasão no ensino superior, mas não dimensiona cientificamente as suas causas e nem os fatores que influenciam as taxas de diplomação". (Amaral; ANDIFES, 2008)

O professor aponta alguns fatores que influenciam na evasão classificando-os em aqueles que se relacionam ao próprio estudante; aqueles relacionados ao Curso e à Instituição e os fatores socioculturais e econômicos externos. Explicita o professor:

Com referência aos fatores individuais, atribui às habilidades de estudo relacionadas à personalidade em decorrência da formação escolar anterior e vincula à escolha precoce da profissão as dificuldades pessoais; Quanto aos fatores internos às instituições, relaciona os currículos desatualizados, alongados; rígida cadeia de pré-requisitos, além da falta de clareza sobre o próprio projeto pedagógico do curso; as questões didádico-pedagógicas: critérios impróprios de avaliação do desempenho discente; falta de estrutura de apoio ao ensino, tais como: laboratório de ensino, equipamentos de informática, etc. Quanto aos fatores

\footnotetext{
${ }^{19}$ Oscar Hipólito- pesquisador do Instituto Lobo para o desenvolvimento da educação da Ciência e da Tecnologia.

${ }^{20}$ Associação Nacional de Dirigentes das Instituições Federais de Ensino Superior.
} 
externos às instituições, atribui os relativos ao mercado de trabalho. Relaciona ao reconhecimento social da carreira escolhida à desvalorização da profissão, por exemplo, o "caso" das licenciaturas. (Amaral, ANDIFES, 2008)

Já para Sabrina Moehlecke, Coordenadora de Extensão da Faculdade de Educação da UFRJ, no caso da evasão por curso o principal fator é a escolha prematura da carreira a ser seguida. No que diz respeito à instituição, refere-se à organização do currículo que geralmente é fragmentado e especializado, sem uma visão de conjunto - e a pouca oferta de cursos noturnos nas universidades federais acabam afastando os estudantes que precisam trabalhar.

Para Carlos Renato Theóphilo em seu estudo intitulado "Evasão no Ensino Superior: Estudo dos fatores causadores da evasão no Curso de Ciências Contábeis da Universidade Estadual de Montes Claros - UNIMONTES" ao examinar os fatores que contribuem para a evasão no ensino superior afirma que "pode ocorrer evasão por vários motivos: trabalho, doença grave ou morte, transferência de domicílio, etc." (Theóphilo, Carlos Renato, p. 05).

Theóphilo considera ainda, que é importante investigar os fatores causadores da evasão no âmbito das diversas instituições e cursos, cita Biazus apud Silva (2005)

\footnotetext{
Por mais que se pesquisem os fatores determinantes da evasão discente, percebe-se que os mesmos se manifestam em graus distintos nos mais variados cursos das Instituições de Ensino Superior - IES, não havendo lógica uniforme que explique homogeneidade à sua ocorrência no conjunto de cursos". (Biazus apud Silva, 2005.p.6)
}

Portanto, investigar as causas motivadoras que impulsionam a evasão em cada instituição de ensino superior, torna-se uma tarefa importante para o desenvolvimento de ações que realmente possam combater ou minimizar os fatores determinantes à evasão de estudantes nas universidades. Isto significa que o fenômeno da evasão no ensino superior deve ser estudado de forma aprofundada, pois somente a partir do conhecimento sobre suas causas poderão ser criadas estratégias eficazes para solucionar esta questão.

Um estudo significativo, no que diz respeito ao fenômeno da evasão de estudantes na Universidade Federal Fluminense - UFF foi realizado pelo professor André Brandão da Escola de Serviço Social e do Programa de PósGraduação em Política Social da UFF. Ao nos apresentar dados referentes ao ano de 2005, o professor identifica que a evasão está relacionada, dentre outros fatores ao perfil do curso de graduação. Os cursos que possuem maior 
valorização social, maior disputa no concurso vestibular e consequentemente que possuem em seu corpo docente estudantes com melhores condições socioeconômicas apresentam menores índices de evasão do que aqueles cursos menos valorizados socialmente.

Outro fator identificado pelo referido professor quanto às causas da evasão diz respeito às condições financeiras dos estudantes. "A evasão é consequência inevitável para aqueles estudantes pobres, sem recursos para a manutenção dos estudos superiores." (Brandão, 2009, p.121). Deste modo, para o autor, as condições socioeconômicas dos estudantes, bem como o curso de graduação escolhido relacionam-se diretamente com o fenômeno da evasão nos cursos de graduação da UFF (Brandão et alli, 2009).

Este mesmo estudo aponta ainda que entre os cursos mais disputados no vestibular de 2005 a média de evasão chega a 26,44\%. Já nos cursos menos disputados a média é de $45,34 \% .^{21}$

Pode-se então concluir que a evasão no ensino superior revela-se de diferentes tipos, tais como: evasão do curso, da instituição ou do ensino superior como um todo. Mas cada uma delas tem causas especificas: por problemas financeiros; por dificuldades de acompanhamento acadêmico, a má qualidade de ensino; a falta de informação e expectativa não correspondidas sobre o curso; o mau relacionamento com o professor; a impossibilidade de trabalhar e estudar; e descontentamento com o horário das disciplinas.

Para minimizar as causas e os efeitos da evasão no ensino superior, fazem-se necessárias a implantação de medidas que visem possibilitar a permanência com qualidade dos estudantes. Uma destas medidas refere-se à adoção das políticas voltadas para a assistência estudantil nas IFES.

\footnotetext{
${ }^{21}$ Os cinco cursos mais disputados no vestibular de 2005 da UFF foram: Medicina, Comunicação Social, Direito, Engenharia Mecânica, Ciências Biológicas. Já os cursos de Física, Biblioteconomia, Química, Matemática e Pedagogia foram os menos disputados no mesmo período.
} 


\section{4 . \\ Assistência Estudantil no Ensino Superior}

Para melhor compreensão sobre a questão da assistência, temos que nos reportar um pouco da história da assistência social no Brasil. A assistência social no Brasil sempre foi vista como uma prática emergencial, de caráter compensatório e destinada apenas ao enfrentamento da pobreza. Muitas vezes foi confundida como política de favor e "como algo negativo por conotar um cunho tutelador e compensatório" (Sposati, 1995, p.35). Sob este prisma, em alguns momentos históricos, a assistência social chegou a ser negada por conta de sua associação ao assistencialismo e ao paternalismo, não era percebida como uma política de Estado, mas sim, como uma política de governo operada sob a égide da "bondade" de primeiras-damas.

Em fins da década de 1970 foram ampliadas as discussões sobre a relação entre Estado e Sociedade bem como o papel das políticas sociais dentro do contexto que se desenhava naquele período - depressão econômica, ditadura militar, aumento da pobreza, movimentos de redemocratização política, etc., foram feitas redefinições sobre a assistência social.

O reconhecimento da assistência social como direito e não como favor ganhou força no texto constitucional de 1988 que diz que ela "será prestada a quem dela necessitar, independente de contribuição à seguridade social" (CF.1988. Art.203).

\footnotetext{
Art. 203 - A assistência social será prestada a quem dela necessitar, independentemente de contribuição à seguridade social, e tem por objetivos:

I - a proteção à família, à maternidade, à infância, à adolescência e à velhice;

II - o amparo às crianças e adolescentes carentes;

III - a promoção da integração ao mercado de trabalho;

IV - a habilitação e reabilitação das pessoas portadoras de deficiência e a promoção de sua integração à vida comunitária;

V - a garantia de um salário mínimo de benefício mensal à pessoa portadora de deficiência e ao idoso que comprovem não possuir meios de prover à própria manutenção ou de tê-la provida por sua família, conforme dispuser a lei.
}

A partir daquele momento a assistência ganha status de direito social integrante da política de seguridade social que tem como objetivo preservar a cidadania dos brasileiros. Ao ser de competência da política pública da seguridade social, a assistência migra do âmbito do clientelismo e 
assistencialismo para o âmbito da política social voltada para a defesa de direitos e universalização do acesso aos bens e serviços.

A Lei Orgânica da Assistência Social - LOAS (Lei n. 8.742), sancionada em 07 de dezembro de 1993, regulamentou a condição de política pública assumida pela assistência social na Constituição Federal de 1988. É indiscutível que a LOAS trouxe um novo significado à concepção de assistência social ao situá-la como política de seguridade social destinada à extensão da cidadania aos setores vulneráveis da sociedade brasileira. A Política Nacional da Assistência Social (2004) e o Sistema Único de Assistência Social - SUAS (2005) constituem outro passo em direção à consolidação da assistência social como política de Estado. No entanto, sob muitos aspectos, ela continua sendo vista e operada como algo residual e voltada para o estabelecimento de uma renda mínima assumindo, assim, um caráter compensatório diante das falhas deixadas pelas outras políticas. Nessa perspectiva, à assistência ainda está agregada a uma noção de pobreza que a aproxima mais de uma ação humanitária do que de uma política social destinada a equacionar a desigualdade e a injustiça social.

Assim entendemos que educação e assistência social, enquanto políticas sociais, encontram-se no campo dos direitos sociais e atuam na promoção da equidade e da justiça social, exigindo para isso ações de intervenção estatal.

Segundo a professora da Universidade Federal de Pernambuco - UFPE, Cristina Arcoverde em palestra proferida na $47^{\text {a }}$ Reunião do FONAPRACE Assistência Estudantil no Contexto da Expansão e da Reestruturação das Instituições Federais de Ensino Superior- que aconteceu em Brasília, dia 6 de maio de 2010, a professora define a assistência estudantil como uma modalidade da assistência social:

A Assistência estudantil é na verdade uma modalidade da assistência social que vem sendo defendida, proposta e executada no âmbito das Instituições Federais de Ensino brasileira (IFES) há algum tempo. As IFES são um dos espaços que reúne demandas reprimidas da sociedade, demandas atendidas e não atendidas no seu interior, e ao mesmo tempo procura efetivar o direito à educação superior.

Acrescenta ainda que:

A assistência estudantil na universidade pública deve articular e contribuir para levar a um plano civilizatório superior de bem-estar aos usuários de dois direitos sociais fundamentais: o de assistência, que com a saúde e a previdência compõe o tripé da seguridade social brasileira, e a educação como seu sustentáculo. (Arcoverde, 2010) 
Para Arcoverde (2010) a educação é a viga mestra de todo o conjunto dos direitos sociais e estão contidos na Constituição Federal desde 1988 e de tal maneira entende que

A Educação e Assistência Social, e a Assistência Estudantil enquanto direitos e políticas públicas numa conjuntura orientada pela perspectiva neo ou pós-liberal de ajuste econômico e de redução dos gastos públicos, particularmente com programas voltados para os direitos sociais. (Arcoverde, 2010)

A relação entre assistência estudantil como direito e o direito à educação superior tem sido construída da mesma forma que vem sendo desafiada pelos impactos das históricas desigualdades sociais no Brasil. Mas os elos que as une e fortalece, são os mesmos que as distancia e as fragiliza, sobretudo quando se trata de materialização e exercício da cidadania brasileira. Neste contexto entende-se que no âmbito da educação e da assistência ambas são permeadas por contradições e ambiguidades, cujas ações articulam-se ao processo educativo, ao projeto acadêmico da instituição de ensino, como favor e não como direito.

\begin{abstract}
A assistência estudantil nas instituições de ensino superior partilha ou compartilha dos mesmos ranços e, ou da herança da assistência social no Brasil, e que vem sendo historicamente entendidos e implementados muito mais como favor ou como um dever moral de ajuda pública ou privada ao estudante universitário do que como um direito social. (Arcoverde, 2010)
\end{abstract}

Arcoverde (2010) ressalta que a assistência estudantil deve ser "tratada como direito universalista stricto senso, permanente, como direito de cidadania e como investimento lato sensu e ser compreendida como uma questão política e de política".

Entretanto, o que se tem verificado nos programas de assistência estudantil nas universidades não é bem esta realidade. Na verdade, as ações assistenciais vêm sendo implementadas conforme decisão política dos gestores e nas decisões pautadas na autonomia universitária.

Embora se considere fundamental pensar a assistência estudantil de forma universal, ou seja, para todos os estudantes, da mesma forma que a educação é direito de todos, conforme preconizada na Constituição Federal de 1988, o que vem se configurando é uma assistência para determinados grupos/segmentos, como por exemplo, estudantes oriundos das classes populares, negros, indígenas. De acordo com Almeida (2000), a crise estrutural do sistema 
educacional brasileiro não permite a universalização do ingresso na educação escolarizada.

Da mesma forma a professora Arcoverde acredita que para que haja a universalização dos direitos à educação e da assistência é preciso que haja, por parte dos governantes, vontade política. "Muitas vezes a assistência social e a estudantil são confundidas igualmente com o fisiologismo político, tidas como benemerência ou política de favor, e vistas como "algo negativo por conotar um cunho tutelador e compensatório". (Sposati, 1995, p 35).

Arcoverde (2010) afirma ainda neste contexto que finalmente a assistência social transitou do campo do assistencialismo para o de política social pública, portanto para o campo dos direitos, da universalização dos acessos e da responsabilidade estatal.

A Constituição Federal de 1988 e a Lei Orgânica da Assistência Social LOAS no 8.742 de 07 de dezembro de 1993 representaram essa possibilidade ao fundamentar o reconhecimento da assistência social como direito social, inserindo-a como política da seguridade social e dever do Estado.

\footnotetext{
Art. 203 - a assistência social será prestada a quem dela necessitar, independentemente da contribuição à seguridade social. (Constituição Federal, 1988).
}

Art. 1ํ A assistência social, direito do cidadão e dever do Estado, é Política de Seguridade Social não contributiva, que provê os mínimos sociais, realizada através de um conjunto integrado de ações de iniciativa pública e da sociedade, para garantir o atendimento às necessidades básicas. (Lei n. 8742, 07 de dezembro de 1993).

Assim sendo, entende-se a assistência social como integrante da seguridade social como política pública e que abrange as demais modalidades, e no caso a assistência estudantil. Arcoverde (1993) chama esta política de política compensatória de "complementaridade às demais políticas setoriais, compensando as deficiências dessas políticas, como é o caso da política de assistência estudantil na educação superior".

Para pensar em política de assistência ao estudante, observa-se que esta vem passando por uma evolução crescente e adquirindo uma maior institucionalidade. Fato este, advém das ações voltadas para assistência aos estudantes, editada através da Lei de Diretrizes e Bases da Educação - LDB que aborda a assistência ao estudante nos seguintes termos: 
Art.94- A União proporcionará recursos ao educando que demonstrem necessidade e aptidões para estudos, sob duas modalidades:

a) Bolsas gratuitas para custeio total dos estudos;

b) Financiamento para reembolso dentro de prazo variável, nunca superior a quinze anos. (Lei 4.024, 1961)

No início dos anos 70 foi criado o DAE - Departamento de Assistência Estudantil, vinculado ao MEC, que implantou alguns projetos voltados para a assistência ao estudante. Através do decreto federal n. 69.927, de 13 de janeiro de 1972 foi criado o Programa Trabalho que "tinha como objetivos levar aos estudantes carentes de recursos possibilidades materiais para a conclusão de seus estudos com possibilidade de complementação educacional e exercício profissional" (Menezes, 2003, p.48).

Outra iniciativa voltada para a garantia da permanência dos estudantes no ensino durante a década de 1970 foi o Movimento de Casas de Estudantes.

Em 1971, no Governo de Emílio G. Médici é instituída a segunda Lei de Diretrizes e Bases, n. 5.692/71. O ensino passa a ser obrigatório dos sete aos 14 anos. O texto também prevê um currículo comum para o primeiro e segundo graus e uma parte diversificada em função das diferenças regionais.

Em 1987 foi criado o Fórum de Pró-Reitores de Assuntos Comunitários e Estudantis- FONAPRACE, que é um órgão de assessoramento da ANDIFES (Associação dos Dirigentes das Instituições Federais de Ensino Superior) que tem como objetivo discutir assuntos pertinentes à comunidade acadêmica das Instituições Federais de Ensino Superior - IFES. O FONAPRACE tem origem das discussões realizadas desde o início dos anos de 1980, nos encontros regionais e nacionais dos Pró-Reitores que vinham abordando demandas, limites e possibilidades das IFES no que diz respeito à assistência estudantil.

O FONAPRACE surgiu em um momento de efervescência política e social no qual eram solidificadas as lutas dos movimentos para a implantação do Estado democrático de direito. Dos encontros do Fórum resultaram conclusões que evidenciaram a urgência em estabelecer políticas que possibilitem o acesso, a permanência e a conclusão do ensino superior, com qualidade. No tocante ao acesso refere-se "a democratização através da expansão da rede pública, bem como na abertura de cursos noturnos. A democratização da permanência implica na manutenção e expansão dos programas de assistência" (FONAPRACE, 1993, p.110). 
Em 1996, uma nova reforma na educação brasileira foi implantada. Tratase da mais recente LDB - 9.394/96, que trouxe diversas mudanças às leis anteriores, com a inclusão da educação infantil (creches e pré-escola).

Esta nova Lei buscou reestruturar o sistema educacional brasileiro, com regulamentações tanto nas áreas de formação de professores e gestão escolar quanto nas áreas de currículo. Com a LDB/96, mais uma vez foram modificadas as denominações do sistema de ensino brasileiro que passou a envolver a educação básica que consiste da educação infantil (até 6 anos), ensino fundamental (oito séries do antigo primário) e ensino médio (três séries); ensino técnico (agora obrigatoriamente desvinculado do ensino médio), além do ensino superior. A LDB/96 é considerada a mais importante lei educacional brasileira.

Em 2001, é aprovado o Plano Nacional de Educação - PNE - (Lei 10.172/2001), que tem como objetivo a elevação do nível de escolaridade da população brasileira, a melhoria da qualidade do ensino em todos os níveis, a redução das desigualdades socais e regionais e a democratização da gestão do ensino público.

O REUNI (Decreto 6.096 de 24 de abril de 2007) em seu Art. 1ำ expõe a questão da expansão de vagas para as universidades e no seu Art. $2^{\circ}$ menciona as diretrizes para a ampliação de políticas de inclusão, permanência e a assistência estudantil, destacando-se os itens I e V.

Art. 1 Fica instituído o Programa de Apoio a Planos de Reestruturação e Expansão das Universidades Federais - REUNI, com o objetivo de criar condições para a ampliação do acesso e permanência na educação superior, no nível de graduação, pelo melhor aproveitamento da estrutura física e de recursos humanos existentes nas universidades federais

Art. $2^{\circ}$ O Programa terá as seguintes diretrizes:

I - redução das taxas de evasão, ocupação de vagas ociosas e aumento de vagas de ingresso, especialmente no período noturno;

$[\ldots]$

V - ampliação de políticas de inclusão e assistência estudantil.

Os princípios legais estabelecidos pelo FONAPRACE levam a reflexão das práticas institucionais, estabelecendo que as IFES "assumem a assistência estudantil como direito e espaço prático de cidadania, buscando ações transformadoras no desenvolvimento do trabalho social com seus próprios integrantes, o que irá ter efeito educativo e, consequentemente, multiplicador". (FONAPRACE, 2001, p.3). 
Para que as IFES pudessem assumir a assistência estudantil e assim solidificar essa responsabilidade, urge a necessidade de implementar uma política pública da assistência estudantil com novas perspectivas na ampliação de recursos e programas para atendimento às necessidades básicas, como moradia, alimentação e transporte, mas também, criar estratégias que possibilitem uma efetiva inserção social por intermédio de formação ética, cidadã, que não só se restrinja a manutenção e sobrevivência dos estudantes em condições de risco socioeconômico. Desta forma, por sugestão do FONAPRACE foi instituído em 12 de dezembro de 2007 a Portaria Normativa no 39, o Programa Nacional de Assistência Estudantil - PNAES, sendo regido pelos seguintes princípios:

I) gratuidade do ensino;

II) igualdade de condições para o acesso, permanência e conclusão de curso nas IFES;

III) formação ampliada na sustentação do pleno desenvolvimento integral dos estudantes;

IV) garantia da democratização e da qualidade dos serviços prestados à comunidade estudantil;

V) liberdade de aprender, ensinar, pesquisar e divulgar a cultura, o pensamento, a arte e o saber;

$\mathrm{VI}$ ) orientação humanística e preparação para o exercício pleno da cidadania;

VII)defesa em favor da justiça social e eliminação de todas as formas de preconceitos;

VIII) pluralismo de idéias e reconhecimento da liberdade como valor ético central.

IX) Os estudantes participantes do programa serão envolvidos em projetos que se articulem com as atividades de ensino, pesquisa e extensão, ficando, assim, evidenciado o compromisso com o retorno social. (FONAPRACE 2001, p. 07).

Em 19 de Julho de 2010, o Governo Federal finalmente institucionaliza a assistência estudantil através do decreto № 7.234 (Programa Nacional de Assistência Estudantil - PNAES), que tem como finalidade, ampliar as condições de permanência dos jovens na educação superior pública federal, através do atendimento às seguintes ações principais na área da assistência estudantil:

I - moradia estudantil

II - alimentação;

III - transporte;

IV - atenção à saúde;

V - inclusão digital;

VI - cultura;

VII - esporte;

VIII - creche;

IX - apoio pedagógico; e 
$X$ - acesso, participação e aprendizagem de estudantes com deficiência, transtornos globais do desenvolvimento e altas habilidades e superdotação.

Este programa preconiza que as ações de assistência estudantil devem considerar a necessidade de viabilizar a igualdade de oportunidades, contribuir para a melhoria do desempenho acadêmico e agir, preventivamente, nas situações de retenção e evasão, para estudantes que apresentem insuficiência de condições financeiras que os impossibilitem de se manterem na universidade.

\section{5 . \\ Assistência ao estudante da UFF: Programas de Bolsas da Assistência Estudantil}

Inicialmente iremos conhecer um pouco do campo da pesquisa, a Universidade Federal Fluminense. A idéia da criação de uma Universidade para o Estado do Rio de Janeiro partiu da Associação Fluminense de professores Católicos em 1946. A Universidade Federal Fluminense - UFF - foi criada em 18 de dezembro de 1960, com o nome de Universidade Federal do Estado do Rio de janeiro - UFERJ. A ela incorporaram-se as cinco Faculdades Federais já existentes em Niterói - Faculdade de Direito de Niterói, Faculdade Fluminense de Medicina, Faculdade de Farmácia e Odontologia, Escola de Odontologia e Escola Fluminense de Medicina Veterinária, agregaram-se ainda os estabelecimentos de ensino estaduais, a escola de Enfermagem do Estado do Rio de Janeiro, Escola Fluminense de Engenharia e a Escola de Serviço Social do Estado do Rio de janeiro e as particulares, Faculdade Fluminense de Filosofia e Faculdade de Ciências Econômicas de Niterói. Em 1964 foi incorporado à Universidade o Hospital Municipal Antônio Pedro, hoje Hospital Universitário Antonio Pedro - HUAP.

Em 1965 a Universidade Federal do Estado do Rio de Janeiro passou a denominar-se Universidade Federal Fluminense, localizada a sua sede em Niterói, a UFF se caracteriza como Universidade de grande porte, com ensino, pesquisa e extensão em quase todas as áreas do conhecimento. É a mais interiorizada das Universidades públicas do Estado do Rio de janeiro, com 
cursos em 16 cidades, incluindo a sede. A UFF ${ }^{22}$ conta com 32 unidades de Ensino Superior; quatro pólos no Interior; 27 pólos de Ensino à Distância; um Colégio Universitário. A área total dos seus campi é de cerca de oito milhões de metros quadrados. Neste conjunto de cursos estão matriculados 38.483 estudantes de graduação, dos quais 32.097 em cursos de graduação presenciais e 6.386 em cursos de graduação à distância. Nos cursos de pósgraduação (lato e stricto sensu), são 11. 675 estudantes, dos quais $1.328 \mathrm{em}$ doutorados, 2.253 em mestrados acadêmicos e 449 em mestrados profissionalizantes.

Quanto à oferta de vagas para os cursos de graduação a UFF ampliou de 4.573 no vestibular 2009, passando para 7.442 em 2010, um aumento de $22 \%$.

Os números acima expostos mostram a trajetória consolidada da UFF ao longo dos anos e demonstram o seu processo de expansão e ampliação na área acadêmica, sendo notada da mesma forma a necessidade de expandir a assistência estudantil na UFF, o que não tem se efetivado.

É fundamental esclarecer que a UFF vem desenvolvendo programas voltados para a assistência estudantil desde a década de 1970. Inicialmente através do DAS - Departamento de Assistência Social, depois o DAC Departamento de Assuntos Comunitários, realizavam atendimentos junto à comunidade universitária com objetivo de garantir a permanência dos estudantes. É importante ressaltar que naquele período a assistência ao estudante ainda não se constituía em um Plano de Governo, o que ocorreu apenas no ano de 2007, com a implantação da Portaria Normativa ํㅜ 39, de 12 de dezembro de 2007 que instituiu o Programa Nacional de Assistência Estudantil - PNAES e em 19 de julho de 2010 através do Decreto o 7.234 como Política de Estado, ou seja, até o ano de 2007 a UFF mantinha com recursos próprios dois Programas da Assistência Estudantil:

1) Bolsa Alimentação: Consistia na isenção do pagamento do valor cobrado no Restaurante Universitário e;

2) Bolsa Treinamento, que consistia na remuneração ao estudante mediante participação em projeto de sua escolha e em sua área de conhecimento. Neste período foram atendidos 400 (quatrocentos) estudantes.

A partir de 2008, com a liberação de recursos através do Programa Nacional da Assistência Estudantil - PNAES foram implantados novos Programas e foi ampliado o número de vagas para os programas existentes.

\footnotetext{
22 Informações obtidas através do Caderno Técnico V.1 do Programa de Expansão e Reestruturação da UFF-2010.
} 
Embora não seja o foco deste estudo analisar o processo de implementação das atuais políticas de acesso e permanência nas Universidades públicas cabe aqui destacar algumas destas fontes que vem mostrando o novo momento no campo das políticas públicas da educação.

Em 2010 a UFF cria a PROAES - Pró-Reitoria de Assuntos Estudantis e amplia o número de programas voltados para a assistência estudantil. Atualmente a PROAES atende a 3.200 (três mil e duzentos) estudantes.

A seguir, elencamos os Programas de Assistência Estudantil desenvolvidos na UFF:

Programa Desenvolvimento Acadêmico;

Programa Bolsa Acolhimento para Estudantes Ingressantes;

Programa Bolsa Alimentação - Restaurante Universitário;

Programa Bolsa Apoio Transporte;

Programa Bolsa Apoio ao Estudante com Deficiência;

Programa Bolsa Emergencial;

Programa Auxílio Alimentação para Estudantes das Unidades Acadêmicas fora da sede;

Programa Auxílio Saúde;

Programa Material Didático;

Programa Auxílio Creche;

Programa Bolsa Atleta;

Programa Apoio ao Estudante Estrangeiro;

Programa Altos Estudos.

Programa de Universalização de línguas Estrangeiras- PULE

Ressaltamos que, mesmo com as ampliações realizadas nos últimos anos, ainda temos que estabelecer algumas estratégias não somente na área dos programas sociais, mas também em programas pedagógicos e acadêmicos, tendo como eixo principal a redução das taxas de evasão.

Desta forma, o que se pode verificar no cotidiano do trabalho na UFF é um número cada vez maior de estudantes que necessitam participar dos programas de assistência estudantil, que é ainda insuficiente. Especialmente os estudantes de classes populares vêm abandonando a universidade por necessidades materiais, pois inúmeras vezes precisam trabalhar para manter-se e, em alguns casos, sua família. Isto evidencia que um número significativo de estudantes deixa a universidade por uma questão de sobrevivência. 
No capítulo que se segue apresentaremos os resultados da pesquisa realizada com os estudantes evadidos dos cursos de Matemática, Química e Física. 


\section{2 \\ Analisando Trajetórias e Percepções}

\section{1. \\ Procedimentos Metodológicos da Pesquisa}

Para alcançar o objetivo proposto pelo estudo, utilizei dados quantitativos e qualitativos. Os dados quantitativos foram utilizados como base para a pesquisa, no entanto, priorizei a abordagem qualitativa, ou seja, o estudo de alguns casos de estudantes evadidos de três cursos das licenciaturas uma vez que a análise da vida escolar desses estudantes e suas trajetórias pós-universidade é o objeto central deste trabalho. Assim para Minayo, as questões qualitativas em uma pesquisa buscam uma maior compreensão no sentido de responder os anseios as vontades que são manifestadas pelo entrevistado.

A pesquisa qualitativa responde à questões muito particulares. Ela se ocupa, com o nível de realidade que não deveria ser quantificada. Ou seja, ela trabalha com o universo dos significados, dos motivos, as aspirações, das crenças, dos valores das atitudes. (Minayo, 2008, p. 21)

Para desenvolver esta pesquisa busquei dados estatísticos fornecidos pela Superintendência da Tecnologia da Informação - STI, órgão da Universidade Federal Fluminense que tem a função de fornecer serviços e soluções de tecnologia da informação no âmbito da UFF. Por meio das informações disponibilizadas, verifiquei que os cursos de Matemática (61,5\%); Química (59,5\%), Física (49,9\%), Ciências Sociais (67,6\%) e Comunicação Social (55,5\%) eram os que possuíam no ano de 2009 o maior percentual de evasão. O que chama atenção nos dados da UFF é que dentre os cinco cursos, três pertencem às Licenciaturas - Matemática, Química e Física. Tais cursos apresentaram-se da mesma forma quando investiguei a média nacional ${ }^{23}$ no mesmo período, Matemática (44\%), Química (36\%) e Física e (34\%).

\footnotetext{
${ }^{23}$ Dados disponibilizados pelo Instituto Nacional de Ensino e Pesquisa - INEP do Ministério da Educação - MEC. Disponível em:http://www.inep. gov.br
} 
Tais dados possibilitaram a localização do problema da evasão e forneceram elementos para delimitação do universo a ser analisado. Deste modo, após o tratamento destes dados, realizei a análise das entrevistas.

Um aspecto importante e decisivo para a realização deste estudo sobre evasão discente no ensino superior foi a revisão bibliográfica. Dentre os estudos encontrados destacam-se os realizados por Silva Filho (2007) que aponta que, no período entre 2000 e 2005, no conjunto formado por todas as IES Instituições de Ensino Superior Brasileiras, a evasão média foi de 22\%, atingindo $12 \%$ nas públicas e nas $26 \%$ nas instituições particulares. Afirma ainda neste estudo que são poucas as IES que possuem um programa institucional regular de combate à evasão, com planejamento de ações, acompanhamento de resultados e coleta de experiências.

$\mathrm{Na}$ literatura sobre o assunto destacam-se Almeida (2001) e Cunha (2001) que buscaram entender e explicar as possíveis causas e consequências da evasão em determinados cursos de graduação ou no ensino superior em geral.

Mônica Reis, estudiosa na questão da evasão universitária, declara que a universidade possui um "tabu para estudar as questões relativas à evasão, mas quando pesquisadas suas causas, estas ficam restritas no âmbito das próprias universidades e não são incorporadas na trajetória de seus estudantes como uma prática de avaliação interna”. ${ }^{24}$.

Após a análise desses dados procurei através do sistema de Identificação ID consultar os dados pessoais e acadêmicos dos estudantes. De posse destas informações, defini a seguinte estratégia de pesquisa: usei a pesquisa quantitativa para definir o universo a ser estudado e a pesquisa qualitativa para captar os dados da realidade de cada estudante evadido, a sua trajetória durante o curso e sua vida após a saída da universidade.

Para atender esta tarefa, usei o que Ludke (1992) chama de equipamento básico da pesquisa: entrevista e análise de documentos. As entrevistas foram realizadas através de um roteiro previamente planejado, semi-estruturada, de forma a permitir ao entrevistado a possibilidade de expressar suas realidades. Este tipo de entrevista permite o sujeito-pesquisado uma liberdade, transformando o momento da entrevista em uma agradável conversa sobre um tema importante e decisivo da vida desses estudantes.

Optei por utilizar a entrevista gravada como recurso metodológico para garantir a veracidade e a riqueza de informações registradas.

\footnotetext{
${ }^{24}$ Mônica Reis - Entrevista na publicação Olhar Virtual - UFRJ- Ed. 183- 2007.
} 
Ao realizar as entrevistas (doze entrevistas), pude constatar que à medida que a conversa se desenvolvia, a relação entrevistado e entrevistador tornava-se agradável, embora o tema evasão para a maioria dos entrevistados ainda era apreendido/sentido como um momento muito doloroso, uma decisão importante para as suas vidas.

Em todo o processo de entrevista procurei ouvir os relatos, não apenas como uma estudante diante de seu objeto de pesquisa, mas como uma pesquisadora diante de um sujeito que tem muito a contribuir para minimizar a questão pesquisada. Esta postura adotada fez com que as narrativas transcorressem com transparência e com signos que para nossos entrevistados eram de fato reais, e não apenas com falas "politicamente corretas" ou carregadas de críticas esvaziadas.

\begin{abstract}
A perspectiva de trabalhar com as narrativas tem o propósito de fazer a pessoa tornar-se visível para ela mesma. O sistema social conscientemente envolve as pessoas numa espiral de ação sem reflexão. Fazemos as coisas porque todos fazem, porque nos disseram que assim é que se age, porque a mídia estimula e os padrões sociais aplaudem. Acabamos agindo sobre o ponto de vista do outro, abrindo mão da nossa própria identidade, da nossa liberdade de ver e agir sobre o mundo, da nossa capacidade de entender e significar por nós mesmos. Cunha (1998, p. 42)
\end{abstract}

É importante ressaltar que em algumas situações durante o processo de entrevistas, a fala dos entrevistados surge sem que fosse feita uma pergunta específica. Algumas falas demonstram certa ansiedade com o tema de nossa pesquisa, especialmente quando nos referimos às questões relacionadas com as razões da evasão.

Outro fato importante a ser destacado é com relação à análise das entrevistas, pois a natureza das informações é complexa e para tal realizei várias leituras dos textos transcritos e em seguida procurei aprofundar as questões relatadas pelos entrevistados ao referencial teórico sobre o tema da evasão discente no ensino superior. Neste aspecto Minayo (2008) considera esta etapa do processo - o de análise e tratamento do material empírico e documental- um conjunto de procedimentos para compreender, interpretar os dados empíricos e articulá-los com a teoria. 
O tratamento do material nos conduz a uma busca da lógica peculiar e interna (grifo do autor) do grupo que estamos analisando (...) a análise qualitativa não é uma mera classificação de opinião dos informantes, é muito mais. É a descoberta de seus códigos sociais a partir das falas, símbolos e observações. A busca da compreensão e da interpretação à luz da teoria aporta uma contribuição singular e contextualizada do pesquisador. (p.27)

Desta forma, procurei realizar reflexões possíveis e necessárias para a produção do conhecimento dos fatores determinantes que levam os estudantes a desistirem do sonho tão desejado, o de obter a diplomação em uma universidade pública e de qualidade.

Para a realização do estudo, foi contabilizado inicialmente o quantitativo por curso no ano de 2009 na categoria cancelamento por abandono, quais sejam: Matemática: 81; Química: 29; Física: 78.

Após a consulta inicial, destacam-se alguns pontos importantes que alteraram o nosso universo quantitativo da pesquisa. Vejamos:

No curso de Matemática totalizam-se 52 estudantes pelas seguintes razões: 22 estudantes não tiveram frequência, isto é, nunca sentaram no banco da UFF, 03 estudantes não tinham nenhum dado registrado para contato, 04 estudantes concluíram o curso na UFF.

No curso de Química, totalizam-se 16 estudantes, pois, 11 estudantes não tiveram frequência, isto é, nunca sentaram no banco da UFF, 02 concluíram o curso na UFF.

No curso de Física, totalizam-se 34 estudantes, pois 23 estudantes não tiveram frequência, isto é, nunca sentaram no banco da UFF, 12 estudantes não tinham nenhum dado registrado para contato, 09 estudantes concluíram o curso na UFF.

Desta forma utilizamos como amostra para o estudo o percentual de $10 \%$ do quantitativo total, isto é, foram entrevistados são: 06(seis) estudantes do curso de Matemática; 03(três) do curso de Física e 03(três) do curso de Química. O quadro 1 demonstra a distribuição de entrevistados por curso e a seguir no quadro 2 demonstra o local de origem dos estudantes. 
Quadro 1- Entrevistados - Por curso de graduação pesquisado

\begin{tabular}{|c|c|}
\hline Entrevistado & Cursos de graduação pesquisados \\
\hline A & Física \\
\hline B & Matemática \\
\hline C & Química \\
\hline D & Matemática \\
\hline E & Física \\
\hline F & Física \\
\hline G & Matemática \\
\hline H & Matemática \\
\hline I & Química \\
\hline J & Matemática \\
\hline K & Matemática \\
\hline L & Química \\
\hline
\end{tabular}

Quadro 2- Entrevistados - Por local de origem/moradia

\begin{tabular}{|c|c|}
\hline Entrevistado & Cidade \\
\hline A & São Gonçalo/RJ \\
\hline B & São Gonçalo/RJ \\
\hline C & Guadalupe/RJ \\
\hline D & São Gonçalo/RJ \\
\hline E & Engenhoca/Niterói \\
\hline F & Maricá/RJ \\
\hline G & Miracema/RJ \\
\hline H & Magé/RJ \\
\hline I & Leme-RJ \\
\hline J & Flamengo/RJ \\
\hline K & Irajá/RJ \\
\hline L & São Gonçalo/RJ \\
\hline
\end{tabular}

Observa-se neste quadro que dos 12 (doze) estudantes entrevistados, 06 (seis) estudantes percorrem entre 24 a $48 \mathrm{~km}$ do seu bairro/município para chegar na Universidade em Niterói. Vejamos: Magé: 48 km; Maricá: 44 km; Guadalupe/RJ: 39 km; Irajá/RJ: 31 km; Leme/RJ: 30 km e Flamengo/RJ: 24 km. Os 4 (quatro) estudantes residentes no Município de São Gonçalo percorrem $13 \mathrm{Km}$ para chegar na UFF. Temos também 1 (um) estudante que reside e estuda em Niterói.

No caso da Unidade Interiorizada em Santo Antônio de Pádua, 01 (um) estudante reside em Miracema percorre $273 \mathrm{~km}$ para chegar à universidade. Percebe-se que a maioria não reside no município sede da Universidade, isto é, em Niterói, percorrem em média mais de $30 \mathrm{~km}$ para estudar, demandando despesas com passagens e tempo de deslocamento. 


\section{2. \\ O Perfil dos Estudantes Entrevistados}

Analisando os Gráficos 1 e 2 percebe-se que a maioria dos estudantes está incluída na faixa etária entre 25 e 30 anos e são do sexo masculino. Este fato nos chama atenção quanto à área do conhecimento das Ciências Exatas por ser historicamente a área do conhecimento eminentemente masculino. Segundo pesquisa realizada em 2001 pelo Conselho Nacional de Desenvolvimento Científico e Tecnológico - CNPq, o Brasil possuía no Diretório dos Grupos de Pesquisa na área de conhecimento das Ciências Exatas e da Terra 7.257 pesquisadores, sendo que apenas 2.214 eram do sexo feminino, contra 5.027 do sexo masculino. Conclui-se, portanto, que ainda nos dias de hoje a área das Ciências Exatas possuiu uma representatividade significativa do sexo masculino.

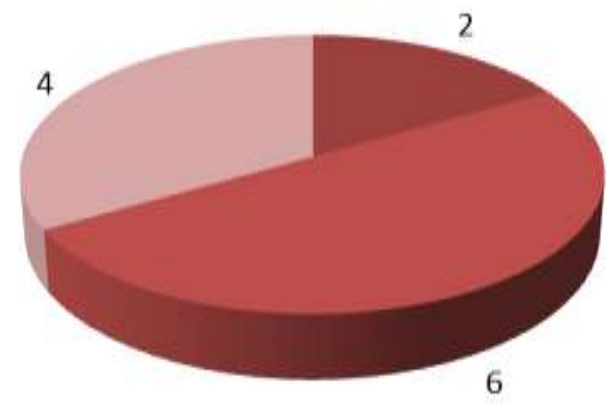

m Até 25 anos $=$ Entre 25 e 30 anos $=$ Acima de 30 anos

Gráfico 1 - Entrevistados - Por faixa etária. 


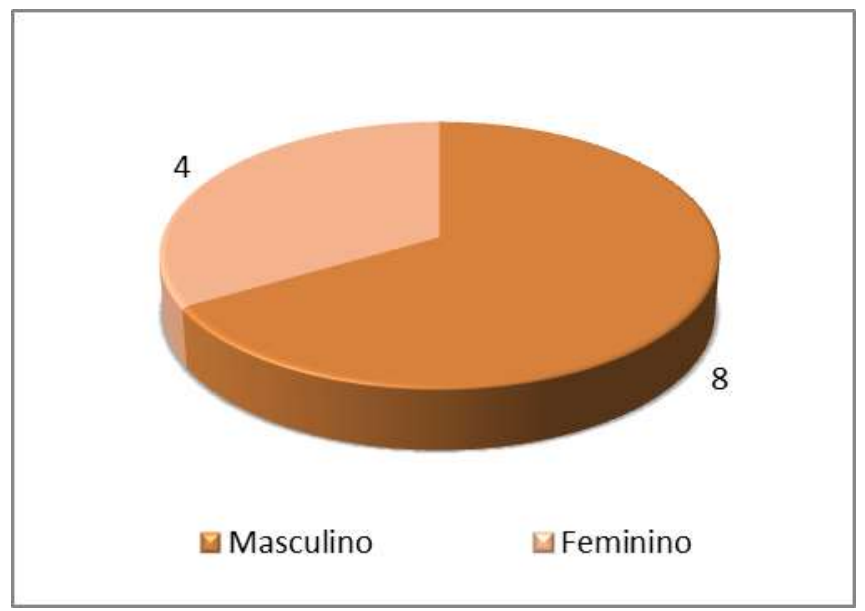

Gráfico 2 - Entrevistados - Por sexo.

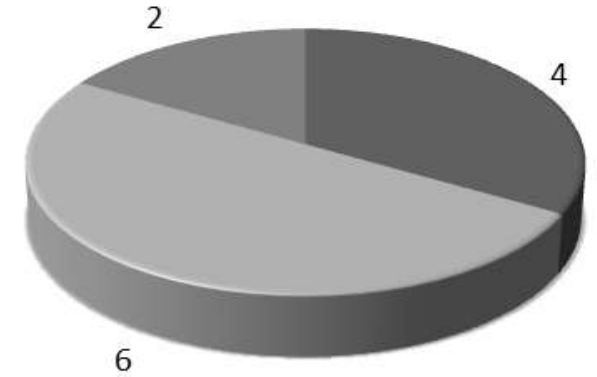

घ Solteiro $\square$ Casado $\square$ Divorciado

Gráfico 3 - Entrevistados - Por estado civil.

Com relação ao estado civil atual dos estudantes, observa-se que a maioria encontra-se casado ou já teve algum relacionamento estável. 


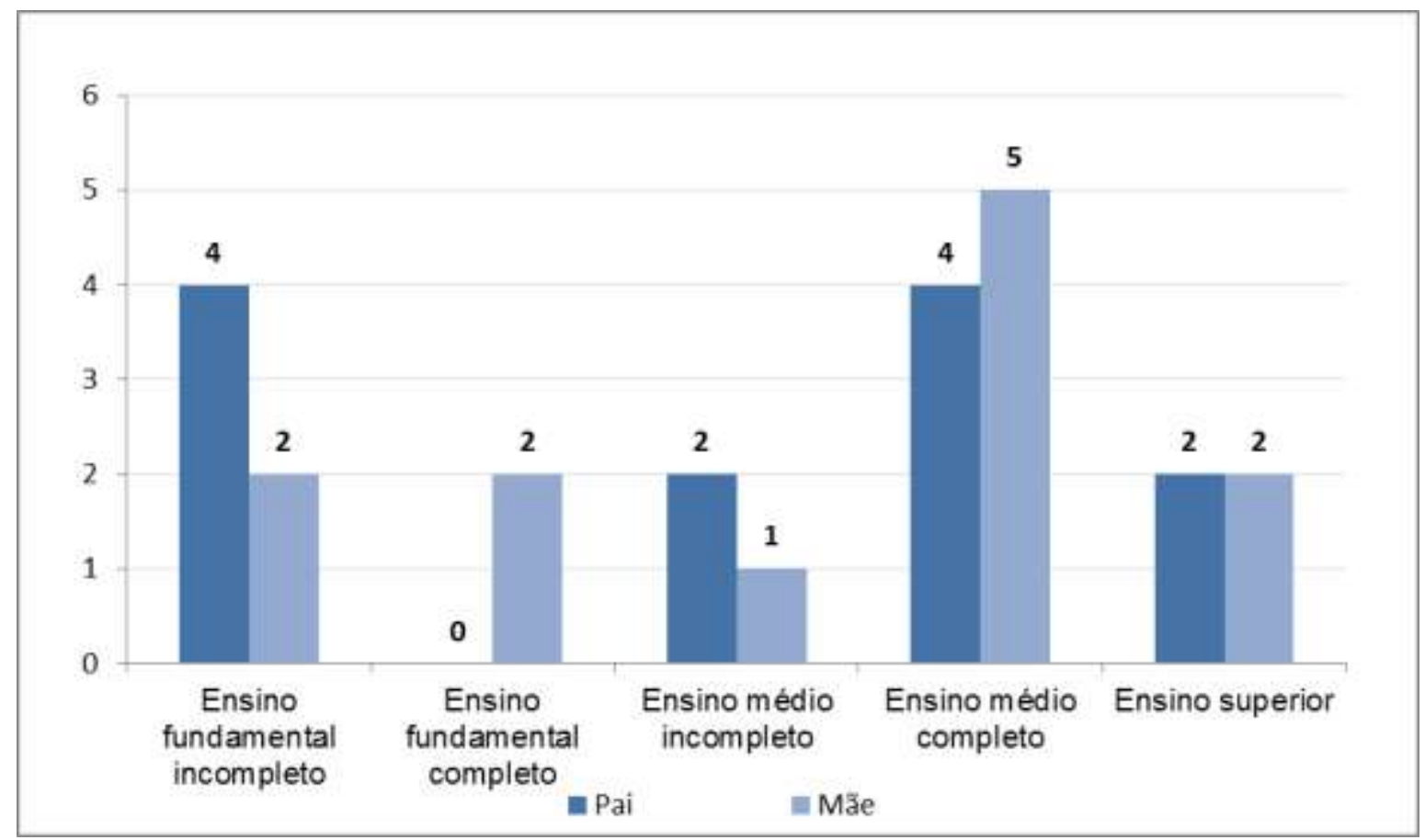

Gráfico 4 - Entrevistados - Por escolaridade dos pais.

No que se refere a escolaridade dos pais e mães (24, no total), a maioria possui o ensino médio completo, totalizando 09 (nove). Idenfificou-se 04(quatro) pais com o curso fundamental incompleto e 02(duas) mães, o que significa que maioria dos pais dos entrevistados tem baixa escolaridade. No que se refere ao curso superior completo, somente 02(dois)pais e 02(duas) mães estão neste grupo. Este contexto nos permite afirmar que majoritariamente os estudantes entrevistados são filhos de pais com escolaridade até o ensino médio. 


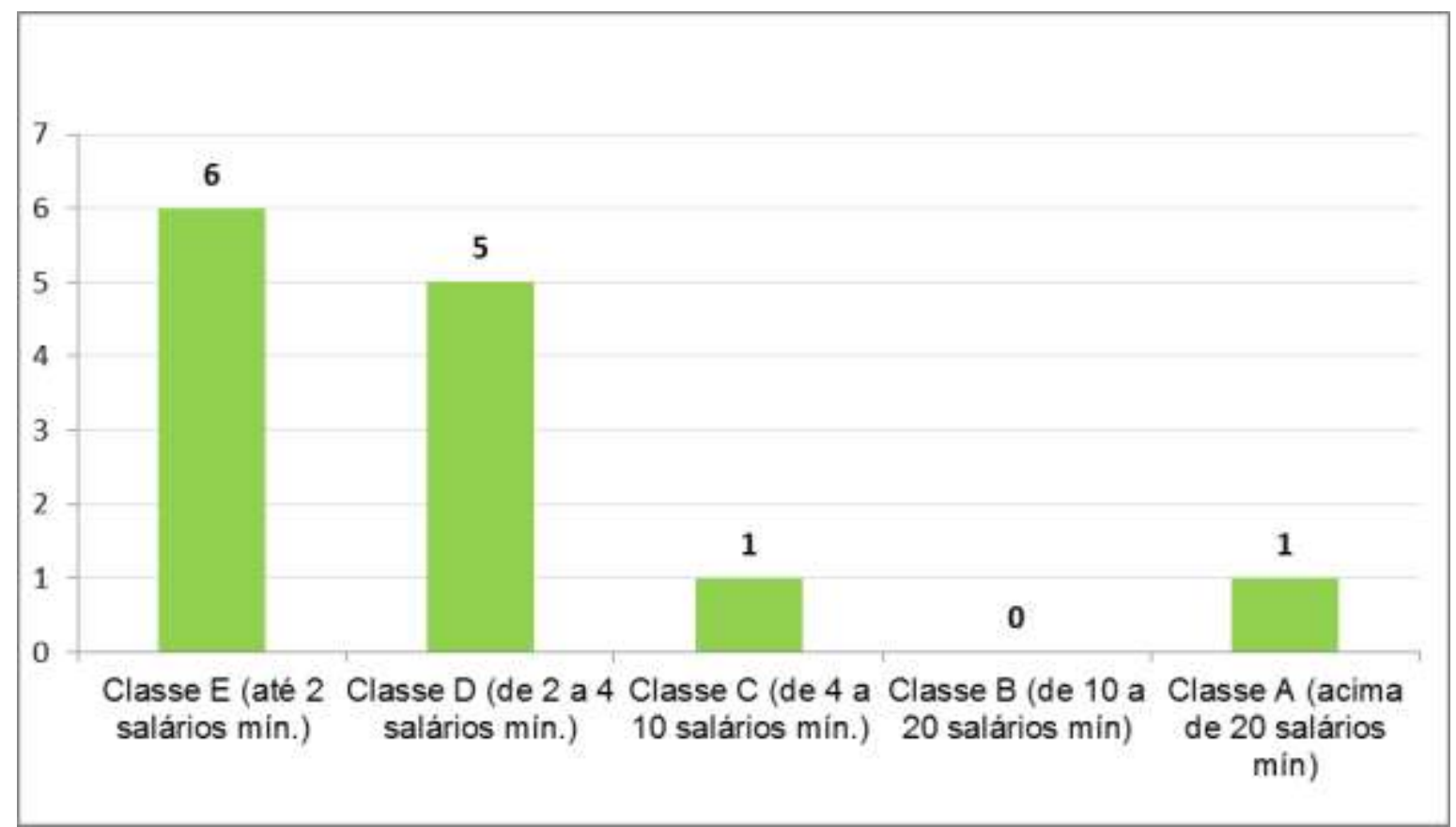

Gráfico 5 - Entrevistados - Por renda média familiar (Em salários mínimos).

Observa-se neste gráfico que a maioria dos estudantes pertenciam, no momento da entrevista, às classes econômicas $D$ e $E$, segundo os critérios do Instituto Brasileiro de Geografia e Estatística (IBGE).

Apenas um entrevistado pertencia à classe $C^{25}$ O IBGE entente por classe econômica a junção das características sociais, demográficas e econômicas das famílias, tomando como base a Pesquisa Nacional por Amostra de Domicílios - PNAD, que é realizada anualmente nas 10 principais capitais e regiões metropolitanas do Brasil. Deste modo o Instituto apresenta uma escala em que classe $A$, diz respeito às famílias mais bem sucedidas economicamente que estão inseridas na faixa salarial a partir de vinte salários mínimos, a classe $E$, refere-se às famílias que possuem maior grau de vulnerabilidade econômica, que se encontram na faixa salarial de até dois salários mínimos.

\footnotetext{
${ }^{25}$ No ato da pesquisa (ano de 2011), o salário mínimo vigente era de $R \$ 545,00$.Segundo a classificação do IBGE, as classes sociais são assim discriminadas: classe $A($ acima de 20SM);classe B(10 a 20SM)classe C(4 a 10SM)classe D(2 a 4SM)classe $\mathrm{E}($ até $2 \mathrm{SM})$.
} 


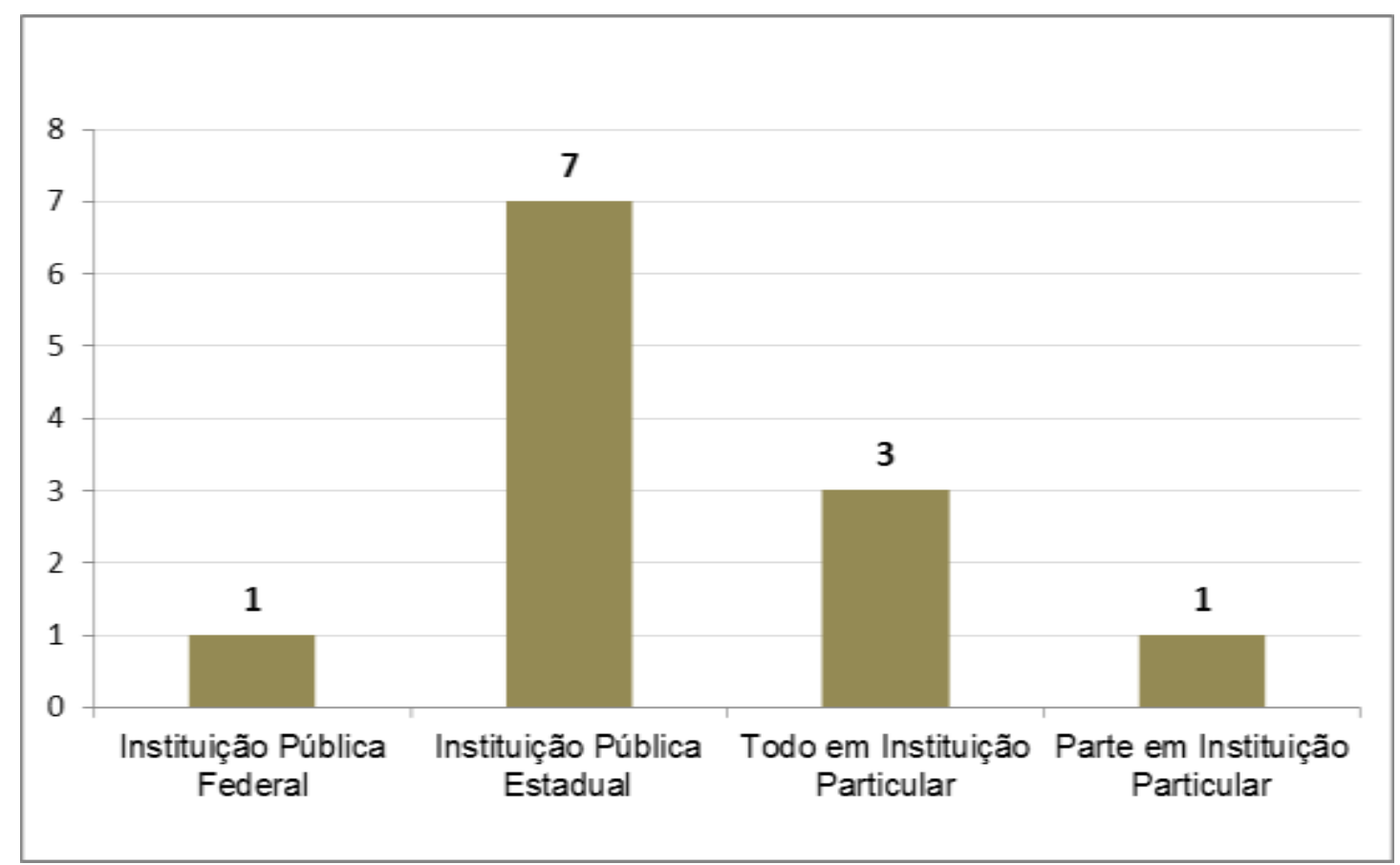

Gráfico 6 - Entrevistados - Por tipo de escola no ensino médio.

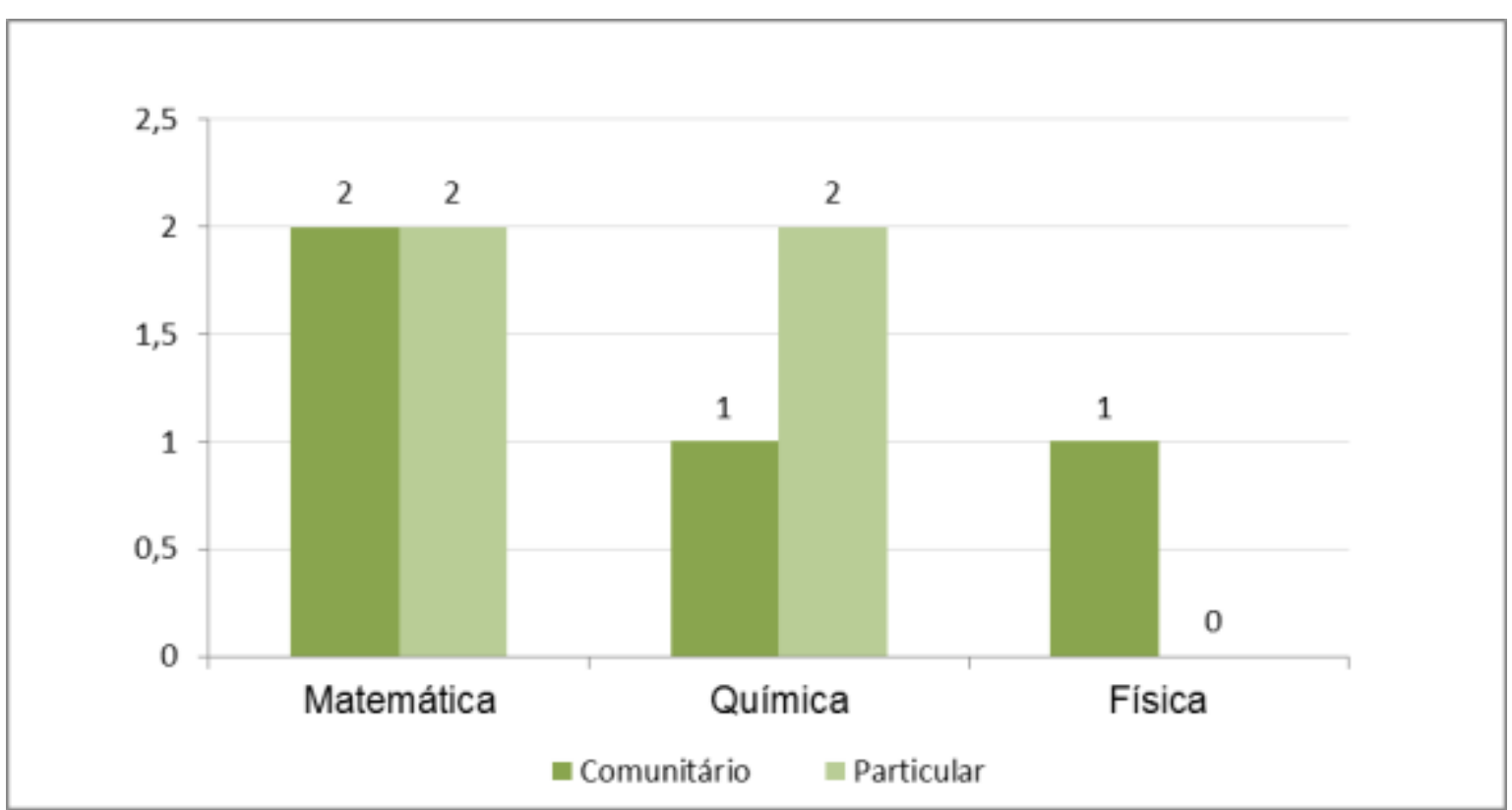

Gráfico 7 - Número de vestibulares prestados - Por curso de graduação pesquisado.

Ao examinarmos os gráficos 6 e 7 percebe-se que mais da metade dos entrevistados são oriundos da escola pública estadual. Considerando a precariedade do ensino público no Brasil, observa-se que a maioria dos estudantes que evadiu, é considerado um estudante de mérito, pois foram aprovados na $1^{\underline{a}}$ vez no vestibular, isto ocorreu nos três cursos pesquisados. 
Embora não considere o mérito o único critério valioso para aprovação na universidade, este é o critério principal para a inserção do jovem na universidade brasileira, percebe-se portanto, que o estudante da UFF é um estudante de qualidade e possui grande potencial acadêmico.

\section{3.}

\section{Análise dos dados: As Narrativas Dos Estudantes Evadidos}

Considera-se importante examinar a questão da evasão universitária através da escuta dos estudantes evadidos dos cursos que propomos analisar, os das licenciaturas de Matemática, Química e Física. Conhecer os fatores determinantes à evasão escolar através das narrativas foi fundamental para a construção da trajetória percorrida pelos estudantes e dando-lhes os significados e reflexões dos fatos vivenciados durante a permanência e a decisão em abandonar o curso. "Quando uma pessoa relata os fatos vividos por ela mesma, percebe-se que reconstrói a trajetória percorrida dando-lhe novos significados. Assim, a narrativa não é a verdade literal dos fatos, mas, antes, é a representação que deles faz o sujeito e, dessa forma, pode ser transformadora da própria realidade". (Cunha 1997). Assim, escutar as histórias contadas pelos ex-estudantes torna-se essencial para se compreender e conhecer sobre as causas que levaram esses estudantes a abandonarem seus cursos de graduação, objeto desse estudo. 


\subsection{1.}

\section{A Trajetória do Estudante Evadido}

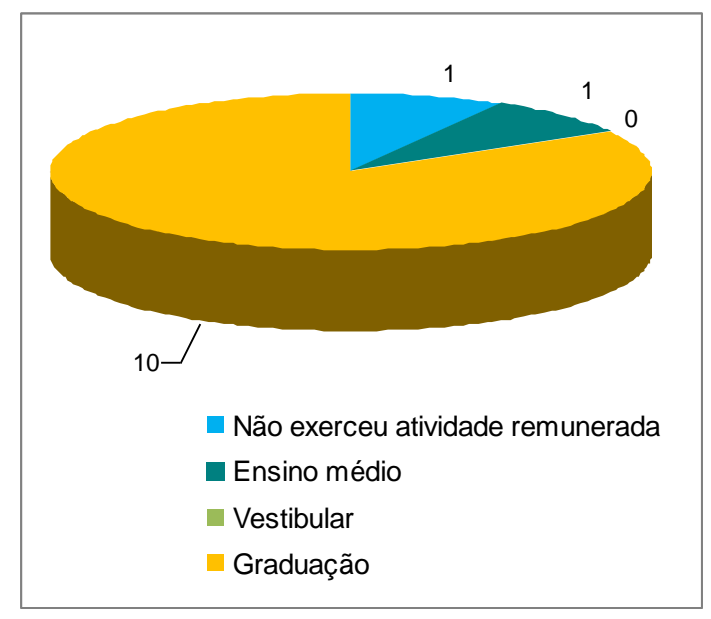

Gráfico 8- Exercício de atividade remunerada durante a trajetória escolar

No que se refere ao exercício profissional durante a trajetória escolar dos entrevistados, percebe-se que a maioria teve sua primeira inserção profissional no mercado de trabalho durante a Graduação.

Este fato é relatado pela maioria dos entrevistados e consideram que a simultaneidade da condição de estudo e trabalho impõe um conjunto de demandas que normalmente passam pelo processo de definição do projeto de vida, mas defrontam a necessidade de um ritmo intenso entre estudar e a necessidade de trabalhar.

As minhas dificuldades na época era financeiras, a minha família era mantida apenas pelo meu pai que trabalhava como pedreiro e minha mãe cuidavam da casa e dos meus irmãos, a gente tinha pouco dinheiro e meu pai queria que eu trabalhasse, ficava me cobrando que eu só gastava e não dava dinheiro pra ajudar em casa e meus irmãos eram pequenos, isso me deixava muito mal. (B)

Gostava muito de estudar na UFF. Sinceramente eu achava que podia render mais, mas precisava estudar também pro concurso e mudar a minha vida e a vida de meus pais. (A)

Sem dúvida o horário das aulas, não entendo porque que o curso precisa ser tempo integral, dificulta quem precisa trabalhar,chegava tarde nas aulas e as vezes tinha que sair mais cedo, e largava no meio da aula, eu ficava desesperada e tinha vergonha de fazer isso, mas não podia largar meu emprego.( I )

A questão do deslocamento, assaltos, enfim o que te falei antes e também a falta de flexibilidade de horário do meu trabalho. Vivia correndo muito. Sempre atrasado, perdendo o começo das aulas e tal e os professores não gostavam que a gente chegasse atrasado, atrapalhava a aula, enfim.. (G). 
Os depoimentos demonstram as dificuldades que os estudantes enfrentaram durante a graduação e a necessidade que tinham para se manter na universidade e o dilema vivenciado entre superar as dificuldades entre o estudo e o trabalho, as necessidades de sua manutenção e permanência na universidade através do trabalho e também na ajuda financeira que desprendiam para as suas famílias.

Os relatos evidenciam que o principal perfil dos estudantes evadidos é constituído das classes populares, especialmente quando estes afirmam a necessidade do trabalho "para ajudar em casa", de que "não podia largar meu emprego", dentre outros aspectos. Frente aos depoimentos, pode-se também dizer que a universidade não está aberta ao estudante que é trabalhador como afirma a entrevistada I: "não entendo porque o curso precisa ser em tempo integral".

Quadro 3- Entrevistados - Por curso e atividade profissional

\begin{tabular}{|c|c|c|}
\hline Entrevistado & $\begin{array}{c}\text { Curso de } \\
\text { graduação }\end{array}$ & Atividade profissional \\
\hline A & Física & Bancária- Banco do Brasil \\
\hline B & Matemática & Militar \\
\hline C & Química & Assistente Administrativo - Estadual \\
\hline D & Matemática & Não exerce atividade no momento \\
\hline E & Física & Comerciário \\
\hline F & Física & Técnico em Informática \\
\hline G & Matemática & Funcionário público Estadual \\
\hline H & Matemática & Microempresário \\
\hline I & Química & Não exerce atividade no momento \\
\hline J & Matemática & Policial militar \\
\hline K & Matemática & Policial Militar \\
\hline L & Química & Atendente de consultório dentário \\
\hline
\end{tabular}

Este quadro demonstra a situação profissional atual dos entrevistados. Percebe-se que a situação de trabalho vivenciada pelos estudantes da UFF, não difere da média nacional, onde os estudantes das classes C1 e C2 somam $82,5 \%$ que exercem atividades não acadêmicas remuneradas (p.28 $)^{26}$. Isto

26 Dados fornecidos da pesquisa do Perfil Socioeconômico e Cultural dos Estudantes da Universidades Federais-2011. FONAPRACE/ANDIFES. 
reforça que são estas as classes sociais que precisam trabalhar para satisfazer suas necessidades materiais básicas.

Outro dado importante que vem reforçar o que identificamos no gráfico 7 é que a metade dos estudantes entrevistados exercem atividades em instituições públicas ocupadas através de concursos públicos (Ministério da Marinha, Polícia Militar e Banco do Brasil) e 1(um) microempresário, o que demonstra que estes estudantes são estudantes de mérito que procuraram através de seus esforços melhorar a sua qualidade de vida e de seus familiares, transformar uma realidade provável em melhoria de vida e construir a sua independência financeira.

Quadro 4- Entrevistados - Por período em que se desvinculou do curso

\begin{tabular}{|c|c|c|}
\hline Entrevistado & Curso de graduação & Período \\
\hline A & Física & 60 \\
\hline B & Matemática & $3^{\circ}$ \\
\hline C & Química & $5^{\circ}$ \\
\hline D & Matemática & $1^{\circ}$ \\
\hline E & Física & $5^{\circ}$ \\
\hline F & Física & $2^{\circ}$ \\
\hline G & Matemática & $1^{\circ}$ \\
\hline H & Matemática & o $^{10}$ \\
\hline I & Química & $5^{\circ}$ \\
\hline J & Matemática & $2^{\circ}$ \\
\hline K & Matemática & $4^{\circ}$ \\
\hline L & Química & \\
\hline
\end{tabular}

Observa-se neste quadro que o maior índice de evasão encontra-se nos primeiros períodos do curso, isto é, entre o $1^{\circ}$ e $04^{\circ}$ período. Entre os 07(sete) estudantes, 04(quatro) da Matemática; 02(dois) da Química e 1(um) da Física. Estes números mostram que os estudantes entrevistados não evadiram frente as primeiras dificuldades encontradas, ao contrário, a maior parte se manteve na universidade no mínimo até o término do $1^{\circ}$ ano, isto é, o estudante não tem perfil de ser um desistente imediato, quando à frente das dificuldades encontradas. Outro aspecto observado diz respeito a dedicação e oportunidades durante os primeiros anos na universidade, os estudantes 
passam pelo menos um ano na universidade até abandonarem o curso, nesse período pouco se envolvem com atividades para além da sala de aula, ou seja, as relações dentro da universidade limitam-se à sala de aula, e pouco sabem sobre o que acontece fora dela.

Nas narrativas abaixo os estudantes demonstram não saberem o que acontece no espaço universitário, ficando de fora muitas das vezes de assuntos importantes dificultando a sua permanência na universidade.

Acho que essas bolsas de auxilio tem que ser mais divulgado, a gente fica por fora, tem que ter mais orientação. ( $A$ )

A gente que precisa dividir o tempo com trabalho e estudo, fica naquela correria pra lá e pra cá, nem dá pra saber das coisas da universidade, aí como saber se mal dá tempo pra estudar. ( C )

Maior divulgação de que existem programas assim. É uma pena que o aluno não saiba disso. ( L )

Que esses auxílios de ajuda fossem mais divulgados, porque as pessoas não tem acesso as informações $(\mathrm{K})$

Neste aspecto, entendemos que o estudante pouco participa das atividades acadêmicas, em virtude do pouco tempo que dispõe para vivenciar a vida universitária e desta forma não desperta para um sentimento de pertencer ao espaço acadêmico. Esta relativa participação em seminários, congressos, estágios, faz com que não se sintam parte integrante da universidade, uma realidade que favorece a evasão.

Quadro 5- Entrevistados - Por situação acadêmica atual (2012)

\begin{tabular}{|c|c|c|}
\hline Entrevistado & Curso de graduação & Situação acadêmica atual \\
\hline A & Física & Cursa Matemática (UERJ) \\
\hline B & Matemática & No momento não cursa o Ensino Superior \\
\hline C & Química & No momento não cursa o Ensino Superior \\
\hline D & Matemática & Cursa Engenharia Civil (Instituição Privada) \\
\hline E & Física & No momento não cursa o Ensino Superior \\
\hline F & Física & Cursa Engenharia Elétrica (UERJ) \\
\hline G & Matemática & No momento não cursa o Ensino Superior \\
\hline H & Matemática & No momento não cursa o Ensino Superior \\
\hline I & Química & Cursa Química (UERJ) \\
\hline
\end{tabular}




\begin{tabular}{|c|c|c|}
\hline $\mathrm{J}$ & Matemática & No momento não cursa o Ensino Superior \\
\hline $\mathrm{K}$ & Matemática & No momento não cursa o Ensino Superior \\
\hline $\mathrm{L}$ & Química & No momento não cursa o Ensino Superior \\
\hline
\end{tabular}

Ao examinarmos o quadro 5 notamos que dos 12(doze) estudantes entrevistados, 08 (oito) abandonaram definitivamente o ensino superior e apenas 04(quatro) estão cursando o ensino superior. Deste total, apenas 1(um) está no curso de origem, os demais mudaram de curso.

Para entender a questão do abandono definitivo do ensino superior e a importância da universidade na vida desses estudantes, indagamos aos entrevistados se havia ainda interesse em retornar à universidade.

Inicialmente, gostaria de deixar bem esclarecido que não foi vontade própria o cancelamento da matrícula e consequente evasão do curso, muito pelo contrário, continuo com a expectativa de poder terminar o curso na UFF. Na época do meu afastamento do curso, eu estava como responsável pela implantação de um Sistema de Controle de Pessoal, gerado pela própria Polícia Militar nas Unidades Operacionais que compõem o quadro da Instituição. Ao termino do meu trabalho e o com o meu retorno à capital, procurei a Universidade para, novamente tentar resolver o problema da minha matrícula e recebi a informação de que nada poderia ser feito, tendo em vista o elevado tempo de afastamento sem nenhuma ciência e o fato da matrícula já ter sido cancelada.( $\mathrm{K}$ )

Eu não teria desistido se o horário fosse mais flexível, mas pretendo voltar ( $G$ )

Bom, eu estava no terceiro período quando fui chamado para a Marinha. Até tentei conciliar os estudos, solicitei a minha transferência para a UNB fui servir em Brasília. Na ocasião senti muitas dificuldades na transferência, muita burocracia, abri processo, e nada adiantou, o tempo foi passando até que desisti de tentar. Será que eu tenho alguma chance de voltar a estudar, preciso fazer o que?(B)

Nunca vou me esquecer daquele dia quando tranquei. Chorei horrores. Tranquei por motivos financeiros. Não sabia da existência de bolsas para alunos pobres. Fiquei desempregada e pouco tempo depois meu pai ficou muito adoentado. Então o dinheiro não dava pra ele me ajudar, pois o auxílio doença demorou muito a sair. Então tive que trancar, aí então não houve jeito, tentei voltar algumas vezes, mas nunca dava, até que não pude mais trancar. Mas sei que um dia eu vou voltar, ainda não desisti não... (L)

Saí contra a minha vontade, fui obrigada, precisava trabalhar, então tive que saí, eu pretendo voltar vou fazer outro vestibular e vou voltar pra realizar meu sonho. (J)

Comecei a trabalhar assim que ingressei na universidade por necessidades financeiras. É caro se manter na faculdade e os meus pais não tinham condições de me manter na faculdade, eu morava longe de Niterói, e os gastos com 
passagens e fora o material, comida. Tava muito difícil, então tive que procurar emprego, mas não desisti ,quero voltar estudar e sei que é muito importante pra mim, pra minha vida .( C )

Os depoimentos apresentados trazem o desejo desses estudantes em retornarem à universidade e o quanto é importante para eles a realização de um dia poder concluir um curso superior. Percebe-se a intenção desses estudantes em obter um diploma e que este sonho permanece nos projetos de vida de cada estudante entrevistado. Entretanto, pode-se afirmar frente aos depoimentos dos estudantes evadidos que a principal causa do abandono é a questão econômica. O fato dos entrevistados serem oriundos de classe popular faz com que os mesmos necessitam trabalhar para a sua manutenção e ajudar nas necessidades básicas de suas famílias. Entende-se que a justificativa para a evasão foi a necessidade financeira.

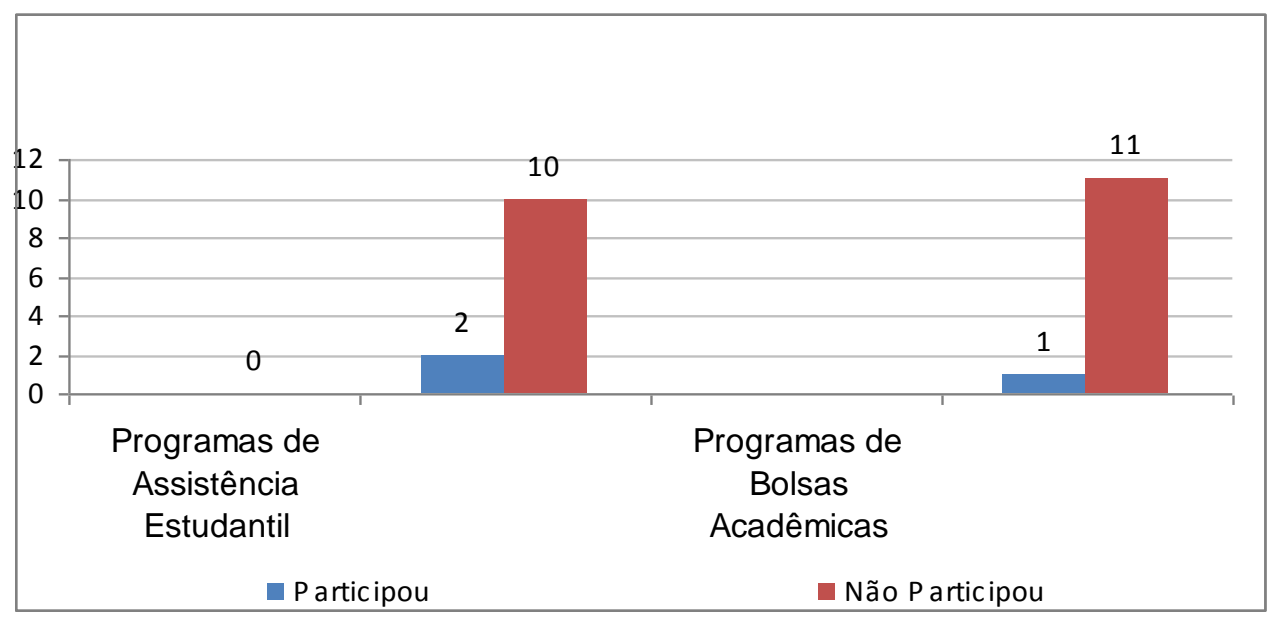

Gráfico 9 - Participação em Programas de Bolsas da Assistência Estudantil e Acadêmicas.

No que se refere a participação dos entrevistados em programas de bolsas acadêmicas e ou da assistência estudantil, nota-se que a maioria não participou de nenhum programa. Este fato pode estar diretamente relacionado com a situação do estudante ter pouco tempo para participar da vida universitária e não conhece os programas institucionais voltados para o estudante tanto na assistência e acadêmicos. Neste aspecto percebe-se que os programas desenvolvidos na universidade não possui ampla visibilidade e são pouco socializadas no meio acadêmico. Este fato pode ter contribuído para não participação dos entrevistados em programas acadêmicos e ou assistenciais, o 
desconhecimento e a desinformação sobre estas atividades na universidade, constituiu assim, em um obstáculo para uma participação mais efetiva do estudante na vida universitária. Os depoimentos abaixo ilustram o total desconhecimento desses estudantes sobre esse assunto e a pouca preocupação da universidade em esclarecer e situar o estudante no espaço universitário.

As pessoas não têm conhecimento destes programas e por isso, facilita que muitos desistam, esses programas deveriam estar informados logo assim que a gente entra na universidade.( C )

Não, não sabia destes incentivos, a gente que precisa dividir o tempo com trabalho e estudo, fica naquela correria pra lá e pra cá, nem dá pra saber das coisas da universidade, aí como saber se mal dá tempo pra estudar, mas eu acho que essas bolsas deveriam estar mais divulgadas assim que a gente entra na universidade. (F)

Não, mas tinha muita vontade de fazer parte de pesquisa, eu gostava de alguns professores e eu achava que a pesquisa deles era muito legal, eu queria ter tido tempo pra isso. ( B)

Não, mas gostaria muito de ter tido tempo pra fazer parte de grupos de estudo e pesquisa, mas infelizmente não dava. ( $\mathrm{K}$ )

Não. Mas sabe como é. Universidade não é pra quem trabalha. Nunca participava dos processos seletivos $(\mathrm{L})$

Eu tentei fazer monitoria, mas não podia me dedicar muito, porque eu tinha que trabalhar aí eu tive que largar, mas eu gostava muito.( A )

Penso que a universidade poderia ajudar mais fazendo cursos de nivelamento para dar um suporte maior e também os auxílios, os estudantes deveriam ser mais bem informados do que a faculdade dá pra ajudar.( D )

Percebe-se através do que foi relatado pelos entrevistados que é essencial que o estudante se sinta parte da universidade, do curso. O processo de integração do estudante ao ambiente da universidade merece ser destacado aqui como imprescindível para que o estudante possa permanecer no curso, na universidade. Podemos afirmar diante das narrativas que a universidade não tem realizado com sucesso as atividades relacionadas ao acolhimento e recepção dos estudantes que ingressam a cada ano.

Tratando especificamente dos programas de assistência estudantil, podese supor que falta à gestão das universidades e os atores envolvidos com a 
assistência estudantil conhecerem com maior profundidade seus prováveis usuários. Não se trata somente de realizar atendimento aos que procuram o setor de assistência estudantil em busca de uma bolsa que atenda suas urgências materiais, mas também desenvolver outras ações que estabeleçam políticas acadêmicas de apoio à aprendizagem, de apoio psicopedagógicos, atividades culturais entre outros, capazes de promover a permanência dos estudantes e uma formação cidadã.

\subsection{2.}

Os Motivos da Evasão nos Cursos das Licenciaturas: Matemática, Química e Física

Quadro 6- Entrevistados - Por Motivo do Abandono do Curso

\begin{tabular}{|c|c|c|}
\hline Entrevistados & Curso de Graduação & $\begin{array}{c}\text { Motivo do Abandono do } \\
\text { Curso }\end{array}$ \\
\hline A & Física & Conciliar trabalho e estudo \\
\hline $\mathrm{B}$ & Matemática & Conciliar trabalho e estudo \\
\hline C & Química & Conciliar trabalho e estudo \\
\hline $\mathrm{D}$ & Matemática & Insatisfação com o curso \\
\hline $\mathrm{E}$ & Física & Conciliar trabalho e estudo \\
\hline $\mathrm{F}$ & Física & $\begin{array}{c}\text { Desmotivação com a } \\
\text { universidade e o curso }\end{array}$ \\
\hline $\mathrm{G}$ & Matemática & Conciliar trabalho e estudo \\
\hline $\mathrm{H}$ & Matemática & Desmotivação com curso \\
\hline I & Química & $\begin{array}{c}\text { Desmotivação com a } \\
\text { universidade }\end{array}$ \\
\hline$J$ & Matemática & $\begin{array}{c}\text { Desmotivação com a } \\
\text { universidade }\end{array}$ \\
\hline K & Matemática & Conciliar trabalho e estudo \\
\hline $\mathrm{L}$ & Química & Conciliar trabalho e estudo \\
\hline
\end{tabular}

Este quadro demonstra que o principal motivo que culminou o abandono do curso foi o horário do trabalho incompatível com os estudos. Entre os 12(doze) entrevistados 7 (sete) declararam sendo este o fator determinante. 
As questões financeiras abordadas pelos entrevistados compreendem o fato que sendo estudantes trabalhadores, estes possuem dificuldades para conciliar os estudos com a jornada de trabalho. O tempo investido no trabalho como forma de sobrevivência impõe, em vários casos, limites acadêmicos, como na participação em encontros organizados no interior ou fora da universidade, nos trabalhos coletivos com os colegas ou nos encontros festivos com a turma. "Vários estudantes se sentem à margem de muitas atividades mais diretamente relacionadas ao que se poderiam chamar investimentos na formação para participação em congressos, conferências, material de apoio." (Zago. 2006.p.235)

Pelos depoimentos abaixo, observa-se que os estudantes entrevistados não participavam efetivamente da academia, isto é, pouco se envolviam nas atividades para além da sala de aula devido ao pouco tempo que tinham para os estudos em virtude do trabalho.

Deixei o curso porque não podia abrir mão do trabalho, e como havia muitas disciplinas que só eram oferecidas de manhã ou à tarde, não consegui conciliar tudo que a universidade oferece pra gente. ( I )

Eu trabalhava no comércio, foi muito difícil, o comércio explora a gente, e estudar não dava muito tempo,não dava pra participar da vida acadêmica. Foi um momento muito difícil pra mim, eu precisava muito trabalhar, a minha família tinha problemas com dinheiro e mal dava pra pagar as minhas passagens pra faculdade, então eu tinha que dar um jeito trabalhar e estudar.( A )

Estava no quinto período quando tive que trancar a matrícula, não tava dando mais conciliar com o trabalho. ( $E$ )

Penso que a universidade poderia ajudar mais fazendo cursos de nivelamento para dar um suporte maior e também os auxílios, os estudantes deveriam ser mais bem informados do que a faculdade dá pra ajudar.

Diante dos fatos mencionados, entende-se que há necessidade de integrar o aluno ao ambiente universitário para assegurar sua permanência até o final do curso. Pode-se constatar que os estudantes tinham consciência que estavam sem horário suficiente para estudar.

Outra razão mencionada pelos entrevistados que demonstra ser bastante importante é a insatisfação com a universidade e ou com o curso, dentre os entrevistados, 05 (cinco) estudantes afirmaram que sentiam muitas dificuldades com o curso: 
Tive muitas dificuldades nas disciplinas que envolviam cálculos e matemática. Eram meu pesadelo ( $\mathrm{C}$ )

Eu tinha muita dificuldade com as disciplinas. Cálculo foi um verdadeiro martírio. ( L )

Gosto de estudar, sempre estudei em escola publica, mas a minha maior dificuldade era com matemática e cálculos.precisava sempre de ajuda dos meus colegas pra estudar.( C )

Nas questões relacionadas às dificuldades encontradas pelos estudantes nas disciplinas que exigem maior embasamento, entende-se que os estudantes são inseridos no ensino superior com dificuldades no conteúdo acadêmico adquiridos no ensino médio. Desta forma, estes estudantes necessitam de uma atenção especial. Enquanto a universidade através das suas coordenações de cursos, colegiados e professores não considerarem esta uma questão determinante a evasão escolar e não promoverem cursos de tutoria e nivelamento no início do curso, certamente a universidade estará contribuindo para o aumento das estatísticas da evasão.

Com relação as dificuldades com a universidade alguns entrevistados relatam que o deslocamento entre um campus para o outro para assistirem uma aula e os constantes assaltos nas mediações da universidade, foi um determinante para a desmotivação de frequentarem o curso.

\begin{abstract}
Acho que o deslocamento entre campus, principalmente à noite. Fazer duas matérias em campus diferentes no mesmo dia, uma seguida da outra era horrível. Sempre tinha atraso, era muito cansativo esse tempo que se gastava indo de um campus para outro. (J)
\end{abstract}

Saíamos às 20h do Valonguinho, por exemplo, e a aula seguinte iniciava também às 20h na Praia Vermelha. Quando chegava a sala o quadro já estava repleto de matéria e perdia parte da explicação. Como costuma ir a pé, tinha receio dos assaltos que outros colegas haviam sofrido. Foi muito frustrante ter que largar, abandonar a UFF. ( F )

Para outros estudantes, a relação com os professores e a incompreensão destes quando os estudantes chegavam na sala de aula atrasados, também foram importantes para a decisão em abandonar o curso, estes motivos são relatados conforme os depoimentos abaixo:

Ninguém entra no curso de Química sem gostar, sem querer. O problema é que temos tantos "impedimentos" que acabamos migrando para outras áreas "mais simples". O professor tem que gostar do que faz, de gostar de ensinar. (L) 
Tem que ver a história do aluno, tem que ver mais o aluno, ver as suas dificuldades e o que pode ser feito para ajudar. É tudo muito mecânico, o professor chega dá a aula e não quer nem saber: $C R$ bom tá no céu. CR baixo é o lixo. Isso precisa ser mudado. (C)

A minha relação com os meus colegas era boa, porém com os professores era um pouco mais difícil, devido a incompreensão de algumas ausências pelo trabalho, chegava tarde às aulas por causa do meu trabalho, isso atrapalhava muito. (E)

A minha relação com os professores tive dois em especial que me marcaram $X$ de Orgânica e o outro de Geral (memória fraca, que ele não saiba disso!!). Excelentes professores, excelentes pessoas. Mas por outro lado, tive outros que não deveriam estar ali... Ao invés de incentivarem, desincentivavam... E muito! Tenho muitas histórias! Claro que "juntou a fome com a vontade de comer", e com tudo eu acabei largando os estudos ( I )

Os professores não gostavam dos atrasos e das faltas, mesmo explicando que era por conta do trabalho. (C)

No que se refere às questões de relacionamento com os professores, os estudantes sentem falta de serem acompanhados e vistos mais de perto por parte dos mesmos e que estes reconheçam as dificuldades sentidas pelos estudantes, principalmente os referentes aos aspectos pedagógicos dos cursos. Mas ao mesmo tempo que apontam este fato como dificuldades, para outros estudantes, a relação com os professores é um facilitador.

Olha, tirando alguns professores estrangeiros, a relação era muito boa com os outros professores e colegas, os meus amigos me ajudavam nas matérias, que eu não entendia ( $F$ )

O entendimento das aulas de física, principalmente pela qualidade dos professores, a UFF tem muitos professores bons.( F )

Outra questão levantada pelos estudantes diz respeito a opção equivocada pelo curso, este fato pode ser demonstrado pelos depoimentos a seguir.

Olha durante esse tempo eu percebi que matemática é pra quem estuda e foca o que está estudando. Eu não tinha esse foco, percebi que não queria ser pesquisador e nem professor. Do $4^{\circ}$ período em diante tornou-se um curso que só serviria pelo diploma. Não achei as matérias difíceis, mas não tive bom aproveitamento porque não me dedicava o suficiente. Acho que eu me decepcionei com o curso aí eu fui desanimando, desanimando e depois estava com o casamento... $(\mathrm{H})$ 
Gostaria de ter feito veterinária, porém sabia que não tinha condições de disputar com outros alunos de escolas particulares. ( C )

Porque eu queria mesmo era fazer Farmácia. Mas enfim, quem não tem cão caça com gato, né? ( L )

Percebe-se nestes relatos, que a opção por cursar a licenciatura não expressa a opção pelo magistério, mas sim a falta de opção mediante as suas condições socioeconômicas, alguns estudantes desistem de tentar as carreiras de maior prestígio e ou de sua preferência e optam por cursos menos procurados,onde a relação candidato/vaga no vestibular sejam menores. Assim, mesmo tendo pouco interesse em ingressar de fato na profissão escolhida, a opção do curso em questão vai sendo adaptada a partir de um conhecimento prático daquilo que está ou não ao seu alcance.

Após elencar os fatores determinantes à evasão nos cursos das licenciaturas da Matemática, Química e Física na UFF, pode-se observar que os entrevistados têm conhecimento dos motivos que levaram a abandonar o curso, que não estão alienados a esses fatores. Considera-se relevante salientar, que a escuta desses relatos são dados significativos, pois o fato de que a maioria dos entrevistados formularam ideias semelhantes, isto é, demonstraram que conciliar estudo e trabalho dificulta a participação mais efetiva as atividades acadêmicas, como também, relacionam como determinante a evasão, a desmotivação do curso ou a decepção com universidade. Lamentam-se também quanto ao deslocamento para um campus e outro em um pequeno espaço de tempo para assistirem as aulas, acarretando atrasos e perda de conteúdos. Alegam ainda, problemas relacionados a dificuldade de aprendizagem e a falta de sensibilidade dos professores em alguns aspectos, não com relação ao ensino ministrado mas por ações e atitudes, isto é, procuram aquele professor que se preocupa com as suas dificuldades, com o seu desempenho acadêmico, um professor/orientador para a sua vida acadêmica. Por outro lado, alguns estudantes atribuem como facilitador para o seu aprendizado os bons professores e a estrutura da universidade. 


\subsection{3. \\ Propostas dos Estudantes para Evitar a Evasão Universitária}

Conforme foi abordado anteriomente, os motivos que levam os estudantes à evasão são inúmeros, como destaca Hipólito (2007). Fatores como a pouca oferta e divulgação, dentro da Universidade de programas que objetivem à permanência, insuficência de programas de acompanhamento pedagógico e inflexibilidade da grade curricular são os principais fatores apontados pelos estudantes entrevistados que contribuíram para a evasão.

Através das narrativas abaixo, os estudantes expressaram suas opiniões para que a universidade evitasse a evasão. Percebe-se que os estudantes que evadiram possuem clareza da situação vivenciada, registram suas sugestões de forma consciente e preocupam-se com a situação de seus colegas e do futuro da universidade.

Com relação à forma de atuação da Universidade junto aos estudantes, os entrevistados apresentam propostas de reformulações em diversos aspectos:

\section{Grade curricular}

Eu acho que a UFF tem que ser mais pragmática no ensino. Tem ensino pra professor e tem ensino pra pesquisador. São coisas diferentes que as abordagens devem ser diferentes e que as disciplinas também devem ser diferentes. Poderiam realizar palestras motivacionais. Isso funciona para evasão no trabalho e deve funcionar para evasão universitária. As palestras temáticas também são de enorme importância, mas para atrair os alunos tem que perguntar a eles o que fazer. ( $\mathrm{H}$ )

Que devem Ignorar o CR. Prestem mais atenção aos alunos. Na UERJ eu já fiz iniciação também, mas não me rendeu outro artigo. Mas assinei como iniciação. Isso logo no meu $1^{\circ}$ semestre lá, ainda nem tinha CR... Só minha "bagagem"... ( I )

\section{Acompanhamento Pedagógico}

Bom eu assisti vários colegas desesperados em acompanhar o ensino, eles tinham pouca base, o ensino médio deles era muito fraco. Acho que a universidade deveria investir mais em monitores que pudessem ajudar os mais fracos de conteúdo, pelo menos durante os três primeiros períodos e também deveria ter mais auxílios para os alunos mais carentes. (B) 
Acho que o curso exige muito, e quem não tem uma boa base precisa se esforçar bastante. Penso que a universidade poderia ajudar mais fazendo cursos de nivelamento para dar um suporte maior. (D)

Acho só que teriam que arrumar um jeito de auxiliar os alunos que trabalham, pois é difícil trabalhar e estudar e ainda perder as matérias por causa do trabalho e também concentrar mais, as aulas deveriam ser no mesmo lugar.( $F$ )

\section{Estrutura Administrativa}

UFF tem que rever os horários de aulas. Fica muito ruim pro aluno trabalhador, estudar. $E$ acho que essas bolsas de auxilio tem que ser mais divulgado, a gente fica por fora, tem que ter mais orientação. ( $A$ )

Também os auxílios, os estudantes deveriam ser melhor informados do que a faculdade dá pra ajudar. ( D)

Neste sentido, percebe-se que os estudantes possuem clareza e entendimento a respeito da dinâmica universitária inadequada aos seus interesses e necessidades. Acrescentam em seus depoimentos que a universidade deve estar mais atenta às solicitações dos estudantes, demonstram alternativas para a superação de suas demandas, isto é, sinalizam que a universidade precisa estar mais próxima da realidade de cada estudante.

Com relação aos Programas de Auxílios e Bolsas da Assistência Estudantil, nota-se que os entrevistados apontam a pouca divulgação de informações acerca dos Programas de Assistência como um dos principais motivos de seu abandono.

Que esses auxílios de ajuda fossem mais divulgados, porque as pessoas não tem acesso as informações na uff, você viu como foi difícil pra mim ter uma orientação que realmente me ajudasse. $(\mathrm{K})$

As pessoas não têm conhecimento destes programas e por isso, facilita que muitos desistam, esses programas deveriam estar informados logo assim que a gente entra na universidade ( C)

Os entrevistados acreditam que é preciso que a Universidade reveja seu papel e observe com maior atenção os estudantes através de pesquisas e estudos que tratem a questão da evasão. Como afirma Hipólito (2007) "o Brasil tem poucos estudos sistemáticos e dados nacionais sobre evasão". 
Faz necessário aprimorar o olhar dos docentes e técnico-administrativos para as questões relacionadas aos estudantes, a fim de se criar mecanismos de aproximação entre os mesmos. Entende-se que assim será possível identificar as demandas trazidas pelos estudantes sejam a respeito de questões como frequência, pedagógicas, financeiras, dentre outros, que possivelmente contribuem para a evasão.

O ideal seria uma assistência que permitisse dedicação exclusiva ao estudo, pois, é muito difícil conciliar com o trabalho, principalmente nos cursos integrais. Mas também entendo que existem pessoas que utilizam desta vantagem e não apresentam o rendimento mínimo necessário. A solução é mais complexa e não consigo falar mais devido minha falta de experiência no assunto. ( $E$ )

Eu acho que este problema não é da UFF, e sim das autoridades federais que comandam este país. Eu acho que deveria ter mais ajuda aos alunos que precisam, sabe. Tem também aqueles que precisam trabalhar, mas que também os professores deveriam entender melhor os alunos que trabalham. ( L )

Pesquisas como esta deveriam ser feitas com mais frequencia para que se pudesse montar um termômetro de prováveis causas de evasão e a solução viesse antes que a saída ou abandono por parte do aluno (K)

Percebe-se através dos relatos que os estudantes desejam ao entrar na universidade obter com clareza as informações necessárias para o seu desenvolvimento no ambiente universitário. Para que de fato a universidade possa cumprir efetivamente o seu papel, ela deverá estar preparada em proporcionar aos seus estudantes propostas pedagógicas, corpo técnicoadministrativos dispostos para recebê-los em suas necessidades, isto é, a universidade tem que estar alerta e atenta às necessidades mais prementes da comunidade universitária e do seu papel no contexto social. 


\section{3 \\ Considerações Finais}

$\mathrm{Na}$ presente dissertação de mestrado foram abordadas questões referentes à evasão no ensino superior. Para apreender este fenômeno, optouse por investigar os cursos de Licenciaturas em Química, Física e Matemática da Universidade Federal Fluminense, tomando como base o ano de 2009.

Ainda que seja verificado avanços nos que diz respeito a democratização do acesso e a permanência no ensino superior, por meio das políticas de permanência trazidas pelo Governo Federal, a evasão universitária ainda é um problema a ser resolvido pelas instituições de ensino superior no Brasil.

Em nosso estudo podemos verificar que são múltiplos os fatores que causam a evasão no ensino superior. $\mathrm{Na}$ pesquisa realizada, nossos entrevistados trouxeram à tona aspectos como dificuldade em conciliar trabalho e vida acadêmica, insatisfação com horário e com o curso escolhido como questões que contribuíram para sua saída da universidade.

Foi possível identificar em nosso estudo que a estrutura curricular apresentada pela UFF não ofereceu aos estudantes a possibilidade de uma inserção com qualidade, que pudesse contemplar uma vida acadêmica voltada para o estudante-trabalhador. A falta de condições estruturais e administrativas relatadas, tais como horário das aulas, que demandam uma dedicação exclusiva e integral, o deslocamento de um campus para outro para assistirem uma aula e a falta de segurança nas mediações da universidade, foram motivos que levaram a desmotivação para continuar o curso.

Chama-nos atenção como os entrevistados relatam os motivos que os levaram a abandonar a universidade. Todos os entrevistados têm clareza de sua vivência universitária e reconhecem os fatores que os levaram a sair do curso. Em momento algum os entrevistados culpam a universidade ou os professores, ao contrário, consideram que estudaram em um espaço onde havia excelência de ensino.

Dentre as dificuldades apontadas, merece destaque a falta de comunicação entre a UFF e os estudantes. São inúmeros os relatos de falta de informação quanto aos procedimentos e normas acadêmico-administrativas. Embora reconhecendo que a falta de tempo para vivenciar a universidade 
contribua para o desconhecimento do que acontece dentro da mesma, os entrevistados apontam que a UFF divulga pouco os programas existentes, prazos de processos de seleção, dentre outras, no que se refere às atividades na área da assistência estudantil e acadêmicas.

Em algumas falas observou-se um tom de desabafo dos entrevistados. Alguns relataram que a universidade e, em particular a UFF não se volta para o estudante como um sujeito, mas sim como mero agente reprodutor do saber instituído em sala de aula. Deste modo, para os entrevistados a UFF acaba por não enxergar as especificidades e demandas pessoais trazidas por seus estudantes, não cumprindo assim, seu papel social.

Foi especificamente relacionado aos problemas e dificuldades que viveram em sua trajetória que as falas dos entrevistados se mostraram bastante pontual. Com relação à vida escolar anterior à entrada no curso de graduação, alguns dos estudantes evadidos demonstraram o conhecimento da dificuldade que teriam em determinadas disciplinas. Mesmo relatando serem bons estudantes no ensino médio, as dificuldades com as disciplinas relacionadas a cálculos foram mencionadas, mas não tiveram peso como facilitador para o abandono do curso.

Durante as entrevistas identificou-se que para os entrevistados, o ingresso no ensino superior representava além da aquisição de conhecimento, um investimento para ampliar suas chances no mercado de trabalho. Passar em um concurso público foi um dos fatores que fizeram alguns dos entrevistados abandonarem a universidade, ou seja, para estes sujeitos, a estabilidade no emprego possui um signo maior que um diploma universitário, o que significa que a sua manutenção e de sua família depende do recurso financeiro adquirido pelo trabalho.

Um fato que nos chama atenção refere-se ao desejo manifestado pela maioria dos estudantes evadidos de voltar a cursar o ensino superior. No entanto, em seus relatos alguns apontam esta volta como algo para o futuro, ainda distante da realidade atual.

O que se observou nos relatos que o momento da decisão de sair da universidade, foi pensado e avaliado e foi uma escolha dolorosa. Não foram identificados nas entrevistas, sentimentos de fracasso ou arrependimento por ter abandonado o curso. $\mathrm{Na}$ realidade, os entrevistados entendem o abandono como uma "escolha", uma decisão que precisava, naquele momento ser tomada.

A partir dos depoimentos dos estudantes entrevistados pode-se perceber que é fundamental o processo de identificação dos motivos da evasão estudantil 
para posteriormente desenvolver métodos e ações que identifiquem quais os estudantes são prováveis ao abandono do curso ou da universidade.

Faz-se imprescindível, em nossa análise, estar mais próximo da realidade do corpo discente, instituir estratégias de transformação que possibilitem maior conhecimento dos docentes e técnico-administrativos sobre as realidades trazidas por cada estudante e reorganizar a estrutura curricular dos cursos a fim de possibilitar aos estudantes um maior aproveitamento da vida acadêmica dentro e fora da universidade.

A questão da evasão estudantil diz respeito a toda a universidade, todos os setores devem estar envolvidos nesta questão e precisam refletir sobre sua importância política e social.

Entende-se que a universidade deve se apresentar de maneira propositiva através de ações que contemplem as especificidades de situações vivenciadas pelos estudantes. Estabelecer e implementar uma política de assistência estudantil fundamentada não só nas questões relacionadas ao acesso e permanência do estudante na universidade, significa, de fato reconhecer a Educação Superior Pública como direito social. 
4

\section{Referências Bibliográficas}

ALMEIDA, N. L. T. Educação Pública e Serviço Social. Revista Serviço Social e Sociedade, n 63. São Paulo: Cortez, 2000.

ANDIFES. Associação nacional dos Dirigentes das Instituições Federais de Ensino Superior. Plano nacional de Assistência Estudantil. 2007.

Associação Nacional dos Dirigentes das Instituições Federais de Ensino Superior. http://www.andifes.org.br/. Acesso em: 28 de jan. 2012.

ANDIFES; ABRUEM; SESU; MEC. Comissão Especial de Estudos sobre a Evasão nas Universidades Públicas Brasileiras. Brasília, out.1996.

ANTUNES, R. Adeus ao Trabalho: ensaios sobre as metamorfoses e a centralidade do mundo do trabalho. 12. ed. São Paulo: Cortez; Campinas, SP: Editora da Universidade Estadual de Campinas, 2007.

BARDAGI, M. P.; HUTZ C. S. Evasão e serviços de apoio ao estudante: uma breve revisão da literatura brasileira. Psicologia Revista. n. 14 2005.

BEHRING, E. R; BOSCHETTI, I. Política social: fundamentos e história São Paulo: Cortez, 2007. (Biblioteca básica de Serviço Social; v. 2).

BERNHEIM. C. T.; CHAUÍ .M. Desafios da universidade na Sociedade do Conhecimento.UNESCO. 2008. 
BOBBIO, N. A era dos direitos. Rio de janeiro. Ed. Campus 1992.

BOURDIEU.P. A Miséria do Mundo. Petrópolis. Vozes, 1998.

BRANDÃO. A. Seleção ou exclusão: difícil acesso as Instituições públicas de ensino- Educação e realidade , 2009.

BRASIL. Decreto PNAES - Decreto no 7.234 de 19 de Julho de 2010. Institui o Programa nacional de Assistência Estudantil, 2010.

. Decreto REUNI - Decreto $\mathrm{n}^{\circ} \mathbf{6 . 0 9 6}$ de 24 de Abril de 2007. Institui o Programa de Apoio a Planos de Reestruturação e Expansão das Universidades Federais, 2007.

. Constituição da República dos Estados Unidos do Brasil. Rio de Janeiro, Assembléia Nacional Constituinte, 1934.

\section{Constituição da República Federativa dos Estados Unidos}

do Brasil. Brasil: Rio de Janeiro: Assembléia Nacional Constituinte .1946.

Rio de Janeiro: Assembléia Nacional Constituinte.

Brasília: 1967.

. Constituição da República Federativa do Brasil: 1988.

Brasília: Câmara dos Deputados, 1988.

. Lei de Diretrizes e Bases da Educação Nacional - LDB . lei no 4.024 . 1961. Brasília : Congresso Nacional. 1961.

. Lei de Diretrizes e Bases da Educação Nacional - LDB . lei no9.394, 1996. Brasília: Congresso Nacional. 1996.

. Plano Nacional de educação - PNE. Lei no 10.172. 2001. 
BRASIL. Presidência da república. Lei Orgânica da Assistência Social LOAS. Lei no 8.742. 1993.

- Sistema Único de Assistência Social - SUAS. Norma Operacional Básica .NOB/SUAS. 2005.

BUARQUE,C. A aventura da universidade. São Paulo: Editora da Universidade Estadual Paulista; Rio de Janeiro: Paz e Terra,1994.

CANDAU, V. M. F. Novos rumos da licenciatura. Brasília: MEC/INEP, 1987.

CASTANHO, S. E. M. A universidade entre o sim, o não e o talvez. In: VEIGA, IIma P. A.. Pedagogia universitária: a aula em foco. Campinas, SP: Papirus, 2000.

CHAUÍ, M. Escritos sobre a universidade. Ed. UNESP. 2001.

CLAPP. A. S. (org.). O Social em Questão: políticas de Ação Afirmativa. n. 23. Rio de Janeiro. PUC-Rio, 2010.

COELHO, I. M. Ensino de graduação e currículo. Universidade e Sociedade. ano II, n.5, 1993.

CUNHA, L..A. A universidade crítica. Rio de janeiro: Francisco Alves, 1982.

CUNHA, M. I. Conta-me Agora: As narrativas como alternativas pedagógicas na pesquisa e no ensino. Revista da Educação, v.23. n. 12, São Paulo, 1997. 
DURHAM. E.R. A avaliação do Ensino Superior. In: Contribuições à definição de uma nova política de Ensino Superior. Revista da Associação Brasileira de Mantenedoras de ensino Superior, ano 15, n. 18. Brasília. 1997.

FAVERO, M. L. A Universidade \& poder. Rio de Janeiro: Achiamé, 1980.

FONAPRACE - III Pesquisa Perfil Socioeconômico e Cultural dos Estudantes de Graduação das universidades Federais BrasileirasANDIFES - 2011.

FREIRE. P. Papel da Educação na Humanização. Revista da FAEEBA, Salvador, n. 07, Jan./Junho, 1997.

FUNDAÇÃO CARLOS CHAGAS - FCC. Instituto Lobo para o Desenvolvimento da Educação, da Ciência e da Tecnologia, Cadernos de Pesquisa Fundação Carlos Chagas set/dez. 2007 v. 37 n. 132.

GENTILI, P. Desencanto e utopia: a educação no labirinto dos novos tempos. Rio de Janeiro: Vozes, 2008.

GENTILI, P.; FRIGOTTO. G. A Cidadania Negada- Políticas de exclusão na educação e no trabalho. 3aㅡ edição. Cortez Editora. 2002.

GOMES.J. B. B. A recepção do instituto da ação afirmativa pelo direito constitucional brasileiro. Ação afirmativa \& principio constitucional da Igualdade, Rio de Janeiro: Editora Renovar. 2001.

HOFFMANN. J. Avaliação. Mito \& desafio. Uma perspectiva construtivista. Porto alegre: Educação \& Realidade. 1993.

IAMAMOTO. M.; CARVALHO. R. Relações Sociais e Serviço Social no Brasil -25 Ed. São Paulo: Cortez. CELATS. 2008. 
INEP - Instituto Nacional de Estudos e Pesquisas Educacionais Anísio Teixeira. http://www.inep.gov.br/. Acesso em: 21 de jul. 2011.

LÉDA, D. B.; MANCEBO, D. Reuni: heteronomia e precarização da universidade e do trabalho docente. Revista Educação \& Realidade, Porto Alegre, v. 34, n. 1, p. 49-64, jan./abr. 2009.

LESSA, C.M.R. Democracia e universidade pública: o desafio da inclusão social no Brasil. In: PEIXOTO, Maria do Carmo de Lacerda. Universidade e democracia: experiências e alternativas para ampliação do acesso à universidade pública brasileira, Belo Horizonte:UFMG, 2004.

LOURENÇO.C.T. Programas Institucionais de permanência e seus impactos nas trajetórias de estudantes de origem popular - o caso da Universidade Federal Fluminense. Dissertação de mestrado em Política Social. Universidade Federal Fluminense. Niterói 2009.

LUDKE, Menga; MEDIANO, Z. Avaliação na escola de 1ำ grau: uma análise sociológica. Campinas: Papirus, 1992.

MACHADO, E. A; SILVA, F. P. Ações Afirmativas nas Universidades Públicas: $O$ que dizem os Editais e manuais. In: Entre dados e fatos: Ação Afirmativa nas universidades públicas brasileiras.

MEC - Ministério da Educação. http://www.mec.gov.br/. Acesso em: 20 de mai. 2011.

MENEZES, J. E. A política de assistência ao estudante: A bolsa de trabalho como instrumento de direito para a formação do aluno no CEFET-AL. Dissertação de mestrado em Serviço Social. Universidade Federal de Pernambuco, Recife, 2003.

MINAYO. M. C. S. pesquisa Social: teoria, método e criatividade. Ed. Vozes. 27를 Edição 2008. 
MOEHLECKE. S. Ação afirmativa: história e debates no Brasil. Cadernos de Pesquisa - FCC, São Paulo, n.1, fasc. 117. 2002.

NERI, M. C. A Nova classe média: O lado brilhante dos Pobres. Disponível em: http://www.cps.fgv. br/ibrecps/ ncm2010/ NCM_pesquisa _formatada.pdf. Acesso em: Acesso em: 21 de jul 2011.

PAIVA. A. R. Entre dados e Fatos: Ação Afirmativa nas Universidades Públicas Brasileiras. Ed. PUC Rio. Pallas. 2010.

PANIZZI, W. M. (org.). Universidade: um lugar fora do poder. Porto Alegre: Editora da UFRGS. 2004

PEIXOTO, M. C. L. (Org.). Universidade e Democracia: experiência e alternativas para ampliação do acesso à universidade pública brasileira. Ed. UFMG. 2004

POLYDORO. S. A. J. Evasão em uma instituição de curso Superior: desafios para a psicologia escolar. Dissertação de Mestrado . PUC/ campinas- 1995.

PONCE, A. Educação e luta de classes. $3^{a}$ ed. Ed. Cortez. 1982.

PONTIFÍCIA UNIVERSIDADE CATÓLICA DO RIO DE JANEIRO. PUCRio - http://www2.dbd.puc-rio.br/pergamun/.../0310449 08 cap 02.pdf Acesso em: 09 de ago. 2012.

REIS, M. Evasão: O Tabu da Universidade. Disponível em: http://www.olharvirtual.ufrj.br/2010/index.php?id_edicao=183\&codigo $=1$.

REVISTA GÊNERO- http://www.cbpf.br/ mulher/hildete1.pdf. Acesso em: 20 de mai. 2012. 
RIBEIRO. M. A. O projeto profissional familiar como determinante da evasão universitária: um estudo preliminar. Revista de orientação profissional. v.6. n. 20, 2005.

ROMANELLI, O. O. História da Educação no Brasil. (1930/1973). $2^{\circ}$ ed. Petrópolis; Vozes, 1980.

SAMPAIO. H. Ensino superior no Brasil: o setor privado. FAPESP; São Paulo, 2000.

SANTOS, B. S. A universidade no Século XXI: para uma reforma democrática e emancipatória da Universidade. São Paulo: Cortez, 2004. ( Coleção questões da nossa época; v. 120).

SARMENTO. D. C. Sistemas de Educação no Brasil: Políticas, autonomia e cooperação. Juiz de Fora: Editora UFJF, 2010.

SILVA F. R. L. L; HIPÓLITO, O. Financiamento e expansão do ensino superior. Disponível em: www.jornaldaciencia.org.br/detalhe.jsp?id=62770. Acesso em: 22 de mai 2011.

SILVA, P. B. G. ; SILVÉRIO, V. R. (Orgs.). Educação e Ações Afirmativas: entre justiça simbólica e a injustiça econômica. Instituto Nacional de Estudos e Pesquisas Educacionais Anísio Teixeira, 2003.

SILVA, T. T.; GENTILI, P. Escola S.A: Quem ganha e quem perde no mercado educacional do neoliberalismo ,CNTE, Brasília, 1996.

SPOSATI. A. Assistência Social: Desafios para uma política pública de seguridade social. Conferência Nacional de Assistência Social. Brasília: 1995. 
TEIXEIRA, A. S. Educação no Brasil. $2^{\circ}$ ed. São Paulo. Ed. Nacional; Brasília, INL. 1976.

. Educação e Universidade. Rio de Janeiro. Ed. UFRJ, 1988.

THEÓPHILO. C. R.; MORAES. J. O. Evasão no ensino superior: estudo dos fatores causadores da evasão no Curso de Ciências Contábeis da Universidade Estadual de Montes Claros. 2006.

UFF - Universidade Federal Fluminense. Caderno Técnico, v.1 do Programa de Expansão e Reestruturação da UFF-2010.

. Universidade federal Fluminense - www.uff.br. Acesso em: 20 de mai 2011.

VELLOSO. J. (Org.). Universidade Pública: Política. Desempenho, Perspectivas. Papirus. 1991.

VELHO. G. Biografia, trajetória e mediação. In: VELHO G. ; KUSCHINIR, K. Mediação, cultura e política. Rio de janeiro: Aeroplano Editora . 2001

ZAGO. N. Do acesso à permanência no ensino superior: percursos de estudantes universitários de camadas populares. Revista Brasileira de Educação, v. 11 n. 32 mai/ago. 2006. 


\section{5 \\ Apêndices}

5.1.

Apêndice 1 - Roteiro de Entrevistas

PONTIFÍCIA UNIVERSIDADE CATÓLICA

CENTRO DE CIÊNCIAS SOCIAIS

DEPARTAMENTO DE SERVIÇO SOCIAL

PROGRAMA DE PÓS-GRADUAAÇÃO EM SERVIÇO SOCIAL

CURSO DE MESTRADO

Prezado(a),

Dirijo-me a você para solicitar-Ihe uma entrevista que tem a finalidade de buscar informações sobre o motivo do seu abandono do Curso que freqüentou na Universidade Federal Fluminense. Pretendo utilizar as informações sob a metodologia de uma dissertação com o título "Evasão Estudantil nos Cursos de Matemática, Química e Física da Universidade Federal Fluminense: Quais questões atravessam essa Silenciosa Problemática?" que apresentarei junto ao Curso de Mestrado em Serviço Social da Pontifícia Universidade Católica do Rio de Janeiro - PUC-RJ. Esclarecemos que o processo de seleção dos entrevistados foi aleatório e a sua identidade não será revelada, a entrevista será gravada para melhor qualidade dos dados fornecidos, Esta pesquisa não oferece conseqüências negativas relativas à sua relação social, profissional, familiar, segurança. Informamos ainda, que o objetivo da dissertação é identificar os principais fatores que contribuem para a evasão de estudantes dos cursos de licenciatura em Matemática, Química e Física, 
tomando como base o ano de 2009. Os dados levantados servirão também, para subsidiar propostas de programas de permanência através de implantação de Políticas de Assistência Estudantil. Você deverá assinar o termo de consentimento livre e esclarecido.

Claudia Macedo

Mestranda em Serviço Social

PUC-RJ

\section{ROTEIRO DE ENTREVISTA}

\section{1- PERFIL DO ESTUDANTE:}

1.1- Sexo:

1.2- Idade:

1.3- Naturalidade:

1.4- Estado Civil:

1.5- Endereço:

1.6- Ocupação Atual:

1.7- Principal Provedor da Família:

1.8- Escolaridade do Pai:

1.9- Escolaridade da Mãe:

1.10- Renda Per capita familiar:

\section{2- VIDA PRÉ-UNIVERSITÁRIA}

2.1- Como foi a sua trajetória Escolar no Ensino Fundamental e Médio?

2.2- Como era o seu rendimento escolar?

2.3- Você fez pré-vestibular? Que tipo? Comunitário, particular?

2.4- Quantas vezes prestou vestibular?

2.5- Exerceu atividades profissionais enquanto cursava o ensino médio/durante o pré-vestibular/durante a graduação? 


\section{3- VIDA UNIVERSITARIA}

3.1- Este curso foi a sua primeira opção? Se não, qual foi?

3.2- Qual foi a sua perspectiva profissional com relação ao curso?

3.3- Você escolheu estudar na UFF ou preferia outra Universidade? Por quê?

3.4- Qual(is) o (s) motivo(s) e em que período estava quando desvinculou-se do curso?

3.5- Como foi a sua relação com os professores e com os colegas?

3.6- Quais foram as suas maiores dificuldades durante o curso?

3.7- Quais foram as suas facilidades durante o curso?

3.8- O que você achou de sua dedicação e do seu conceito de rendimento(CR) no curso?

3-9- Você participou de algum Programa de Bolsa Acadêmica( CNPQ, PIBIC, Extensão, Monitoria)?

3.10- Você participou de algum Programa de Bolsa/Auxílio da Assistência Estudantil? Que sugestões daria para implementação de Programas da Assistência Estudantil que evitasse a evasão? 


\title{
5.2.
}

\section{Apêndice 2 - Termo de Consentimento Livre e Esclarecido}

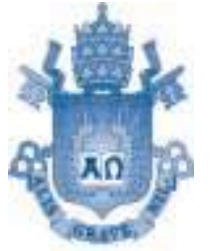 \\ Pontifícia Universidade Católica do Rio de Janeiro \\ Programa de Pós-Graduação em Serviço Social \\ Departamento de Serviço Social
}

Pesquisa: Evasão Estudantil nos cursos de Matemática, Química e Física da Universidade Federal Fluminense: Quais questões atravessam essa Silenciosa Problemática?

\section{TERMO DE CONSENTIMENTO LIVRE E ESCLARECIDO}

Eu, Claudia Macedo, estou desenvolvendo uma pesquisa para minha Dissertação de Mestrado em Serviço Social, junto aos estudantes evadidos dos cursos de Licenciaturas em Matemática, Química e Física da Universidade Federal Fluminense - UFF.

A pesquisa tem como objetivo geral identificar os principais fatores que contribuem para a evasão de estudantes dos cursos de Licenciaturas em Matemática, Química e Física da Universidade Federal Fluminense, tomando por base o ano de 2009.

As informações serão obtidas através de uma entrevista realizada em sala reservada e constará de perguntas a respeito de sua vida acadêmica durante o período em que você permaneceu no curso de graduação da UFF. As entrevistas serão gravadas para melhorar a qualidade dos dados fornecidos. A gravação é imprescindível para a sua participação nesta pesquisa. É importante ressaltar que sua participação é confidencial. Sua identidade não será revelada em nenhuma hipótese, e as leis regulando tais procedimentos serão seguidas quando os resultados do estudo forem publicados. Você pode desistir de participar a qualquer momento e a entrevista será desgravada na hora. 
Esta pesquisa não oferece conseqüências negativas relativas à sua relação social, profissional, familiar, segurança e nem oferece risco à sua saúde. A informação coletada é apenas para pesquisa e não oferece benefícios diretos para você. A sua participação trará como benefício a ampliação do conhecimento acerca de questões relacionadas à evasão no ensino superior e o debate sobre as políticas de assistência estudantil na UFF.

Desde já agradeço.

\section{Declaração e Consentimento}

Declaro ter entendido os objetivos, riscos e benefícios da pesquisa e concordo em participar.

Participante

Pesquisador

Rio de Janeiro, de de 2011. 


\section{Anexos}

6.1.

Anexo 1 - Portaria Normativa № 39, de 12 de Dezembro de 2007 /

Decreto № 7.234, de 19 de Julho de 2010

\section{MINISTÉRIO DA EDUCAÇÃO \\ GABINETE DO MINISTRO \\ PORTARIA NORMATIVA № 39, DE 12 DE DEZEMBRO DE 2007}

Institui o Programa Nacional de Assistência Estudantil - PNAES.

O MINISTRO DE ESTADO DA EDUCAÇÃO, no uso de suas atribuições, considerando a centralidade da assistência estudantil como estratégia de combate às desigualdades sociais e regionais, bem como sua importância para a ampliação e a democratização das condições de acesso e permanência dos jovens no ensino superior público federal, resolve:

Art. 1ำ Fica instituído, no âmbito da Secretaria de Educação Superior SESu, do Ministério da Educação, o Programa Nacional de Assistência Estudantil - PNAES, na forma desta Portaria.

Art. 2ㅇ O PNAES se efetiva por meio de ações de assistência estudantil vinculadas ao desenvolvimento de atividades de ensino, pesquisa e extensão, e destina-se aos estudantes matriculados em cursos de graduação presencial das Instituições Federais de Ensino Superior. 
Parágrafo único. Compreendem-se como ações de assistência estudantil iniciativas desenvolvidas nas seguintes áreas:

I - moradia estudantil;

II - alimentação;

III - transporte;

IV - assistência à saúde;

$\mathrm{V}$ - inclusão digital;

$\mathrm{VI}$ - cultura;

VII - esporte;

VIII - creche; e

IX - apoio pedagógico

Art. 3ำ As ações de assistência estudantil serão executadas pelas IFES considerando suas especificidades, as áreas estratégicas e as modalidades que atendam às necessidades identificadas junto ao seu corpo discente.

$\S 1^{\circ}$ As ações de assistência estudantil devem considerar a necessidade de viabilizar a igualdade de oportunidades, contribuir para a melhoria do desempenho acadêmico e agir, preventivamente, nas situações de repetência e evasão decorrentes da insuficiência de condições financeiras.

$\S 2^{\circ}$ Os recursos para o PNAES serão repassados às instituições de educação superior, que deverão implementar as ações de assistência estudantil, na forma do caput.

Art. 4ำ As ações do PNAES atenderão a estudantes matriculados em cursos presenciais de graduação, prioritariamente, selecionados por critérios sócio-econômicos, sem prejuízo de demais requisitos fixados pelas instituições de educação superior em ato próprio. 
Parágrafo único. As IFES deverão fixar mecanismos de acompanhamento e avaliação do PNAES com vistas a cumprimento do parágrafo $1^{\circ}$ do art. $3^{\circ}$.

Art. 5o As despesas do PNAES correrão à conta das dotações orçamentárias anualmente consignadas ao Ministério da Educação, devendo o Poder Executivo compatibilizar a quantidade de beneficiários com as dotações orçamentárias existentes, observados os limites estipulados na forma da legislação orçamentária e financeira.

Art. 6ㅇ O PNAES será implementado a partir de 2008.

Art. $7^{\circ}$ Esta Portaria entra em vigor na data da sua publicação. 


\section{Presidência da República \\ DECRETO № 7.234, DE 19 DE JULHO DE 2010.}

Dispõe sobre o Programa Nacional de Assistência Estudantil - PNAES.

O PRESIDENTE DA REPÚBLICA, no uso da atribuição que the confere o art. 84, inciso VI, alínea "a", da Constituição:

\section{DECRETA:}

Art. $1^{\circ}$ O Programa Nacional de Assistência Estudantil - PNAES, executado no âmbito do Ministério da Educação, tem como finalidade ampliar as condições de permanência dos jovens na educação superior pública federal.

Art. $2^{\circ}$ São objetivos do PNAES:

I-democratizar as condições de permanência dos jovens na educação superior pública federal;

II - minimizar os efeitos das desigualdades sociais e regionais na permanência e conclusão da educação superior;

III - reduzir as taxas de retenção e evasão; e

IV - contribuir para a promoção da inclusão social pela educação.

Art. $3^{\circ}$ O PNAES deverá ser implementado de forma articulada com as atividades de ensino, pesquisa e extensão, visando o atendimento de estudantes regularmente matriculados em cursos de graduação presencial das instituições federais de ensino superior. 
$\S 1^{\circ}$ As ações de assistência estudantil do PNAES deverão ser desenvolvidas nas seguintes áreas:

I - moradia estudantil;

II - alimentação;

III - transporte;

IV - atenção à saúde;

V - inclusão digital;

$\mathrm{VI}$ - cultura;

VII - esporte;

VIII - creche;

IX - apoio pedagógico; e

$X$-acesso, participação e aprendizagem de estudantes com deficiência, transtornos globais do desenvolvimento e altas habilidades e superdotação.

$\S 2^{\circ}$ Caberá à instituição federal de ensino superior definir os critérios e a metodologia de seleção dos alunos de graduação a serem beneficiados.

Art. $4^{\circ}$ As ações de assistência estudantil serão executadas por instituições federais de ensino superior, abrangendo os Institutos Federais de Educação, Ciência e Tecnologia, considerando suas especificidades, as áreas estratégicas de ensino, pesquisa e extensão e aquelas que atendam às necessidades identificadas por seu corpo discente.

Parágrafo único. As ações de assistência estudantil devem considerar a necessidade de viabilizar a igualdade de oportunidades, contribuir para a melhoria do desempenho acadêmico e agir, preventivamente, nas situações de retenção e evasão decorrentes da insuficiência de condições financeiras.

Art. $5^{\circ}$ Serão atendidos no âmbito do PNAES prioritariamente estudantes oriundos da rede pública de educação básica ou com renda 
familiar per capita de até um salário mínimo e meio, sem prejuízo de demais requisitos fixados pelas instituições federais de ensino superior.

Parágrafo único. Além dos requisitos previstos no caput, as instituições federais de ensino superior deverão fixar:

I - requisitos para a percepção de assistência estudantil, observado o disposto no caput do art. $2^{\circ}$; e

II - mecanismos de acompanhamento e avaliação do PNAES.

Art. $6^{\circ}$ As instituições federais de ensino superior prestarão todas as informações referentes à implementação do PNAES solicitadas pelo Ministério da Educação.

Art. $7^{\circ}$ Os recursos para o PNAES serão repassados às instituições federais de ensino superior, que deverão implementar as ações de assistência estudantil, na forma dos arts. $3^{\circ}$ e $4^{\circ}$.

Art. $8^{\circ}$ As despesas do PNAES correrão à conta das dotações orçamentárias anualmente consignadas ao Ministério da Educação ou às instituições federais de ensino superior, devendo o Poder Executivo compatibilizar a quantidade de beneficiários com as dotações orçamentárias existentes, observados os limites estipulados na forma da legislação orçamentária e financeira vigente.

Art. $9^{\circ}$ Este Decreto entra em vigor na data de sua publicação.

Brasília, 19 de julho de $2010 ; 189^{\circ}$ da Independência e $122^{\circ}$ da República.

LUIZ INÁCIO LULA DA SILVA

Fernando Haddad 


\section{2.}

Anexo 2 - Decreto № 6.096, de 24 de Abril de 2007- Programa de Apoio a Planos de Reestruturação e Expansão das Universidades Federais - REUNI

\section{Presidência da República}

\section{DECRETO № 6.096, DE 24 DE ABRIL DE 2007}

Institui o Programa de Apoio a

Planos de Reestruturação e

Expansão das Universidades

Federais - REUNI.

O PRESIDENTE DA REPÚBLICA, no uso da atribuição que lhe confere o art. 84, inciso VI, alínea "a", da Constituição, e considerando a meta de expansão da oferta de educação superior constante do item 4.3.1 do Plano Nacional de Educação, instituído pela Lei n o 10.172, de 9 de janeiro de 2001,

\section{DECRETA:}

Art. 1ํ Fica instituído o Programa de Apoio a Planos de Reestruturação e Expansão das Universidades Federais - REUNI, com o objetivo de criar condições para a ampliação do acesso e permanência na educação superior, no nível de graduação, pelo melhor aproveitamento da estrutura física e de recursos humanos existentes nas universidades federais.

$\S 1^{\circ}$ O Programa tem como meta global a elevação gradual da taxa de conclusão média dos cursos de graduação presenciais para noventa por cento e da relação de alunos de graduação em cursos presenciais por 
professor para dezoito, ao final de cinco anos, a contar do início de cada plano.

§ 2으 O Ministério da Educação estabelecerá os parâmetros de cálculo dos indicadores que compõem a meta referida no $\S 1^{\circ}$

\section{Art. $2^{\circ}$ O Programa terá as seguintes diretrizes:}

I - redução das taxas de evasão, ocupação de vagas ociosas e aumento de vagas de ingresso, especialmente no período noturno;

II - ampliação da mobilidade estudantil, com a implantação de regimes curriculares e sistemas de títulos que possibilitem a construção de itinerários formativos, mediante 0 aproveitamento de créditos e a circulação de estudantes entre instituições, cursos e programas de educação superior;

III - revisão da estrutura acadêmica, com reorganização dos cursos de graduação e atualização de metodologias de ensino-aprendizagem, buscando a constante elevação da qualidade;

IV - diversificação das modalidades de graduação, preferencialmente não voltadas à profissionalização precoce e especializada;

V - ampliação de políticas de inclusão e assistência estudantil; e

VI - articulação da graduação com a pós-graduação e da educação superior com a educação básica.

Art. 3ำ O Ministério da Educação destinará ao Programa recursos financeiros, que serão reservados a cada universidade federal, na medida da elaboração e apresentação dos respectivos planos de reestruturação, a fim de suportar as despesas decorrentes das iniciativas propostas, especialmente no que respeita a:

I- construção e readequação de infra-estrutura e equipamentos necessárias à realização dos objetivos do Programa; 
II - compra de bens e serviços necessários ao funcionamento dos novos regimes acadêmicos; e

III - despesas de custeio e pessoal associadas à expansão das atividades decorrentes do plano de reestruturação.

$\S 1^{0}$ O acréscimo de recursos referido no inciso III será limitado a vinte por cento das despesas de custeio e pessoal da universidade, no período de cinco anos de que trata 0 art. $1^{\circ}, \S 1^{\circ}$.

$\S 2^{\circ} \mathrm{O}$ acréscimo referido no $\S 1^{\circ}$ tomará por base o orçamento do ano inicial da execução do plano de cada universidade, incluindo a expansão já programada e excluindo os inativos.

$\S 3^{\circ} \mathrm{O}$ atendimento dos planos é condicionado à capacidade orçamentária e operacional do Ministério da Educação.

Art. 4ํ O plano de reestruturação da universidade que postule seu ingresso no Programa, respeitados a vocação de cada instituição e o princípio da autonomia universitária, deverá indicar a estratégia e as etapas para a realização dos objetivos referidos no art. $1^{\circ}$.

Parágrafo único. O plano de reestruturação deverá ser aprovado pelo órgão superior da instituição.

Art. 5ㅇ $\mathrm{O}$ ingresso no Programa poderá ser solicitado pela universidade federal, a qualquer tempo, mediante proposta instruída com:

I - o plano de reestruturação, observado 0 art. $4^{\circ}$

II - estimativa de recursos adicionais necessários ao cumprimento das metas fixadas pela instituição, em atendimento aos objetivos do Programa, na forma do art. $3^{\circ}$, vinculando o progressivo incremento orçamentário às etapas previstas no plano.

Art. 6ำ A proposta, se aprovada pelo Ministério da Educação, dará origem a instrumentos próprios, que fixarão os recursos financeiros adicionais 
destinados à universidade, vinculando os repasses ao cumprimento das etapas.

Art. $7^{0}$ As despesas decorrentes deste decreto correrão à conta das dotações orçamentárias anualmente consignadas ao Ministério da Educação.

Art. 8ํㅗ Este Decreto entra em vigor na data de sua publicação.

Brasília, 24 de abril de 2007; 186 da Independência e 119 da República.

LUIZ INÁCIO LULA DA SILVA

Fernando Haddad

Paulo Bernardo Silva 